\title{
Market Power and Performance: A Cross-Industry Analysis of Manufacturers and Retailers
}

\author{
KUSUM L. AILAWADI \\ Dartmouth College \\ NORM BORIN \\ California Polytechnic and State University
}

PAUL W. FARRIS

University of Virginia

Two recent studies of manufacturer and retailer profitability in the food industry have raised questions about whether the widely cited, but empirically untested, shift of power from manufacturers to retailers has really occurred. Has the marketing community been operating under a misconception or are these studies flawed? This paper uses more complete measures of exercised and potential market power and a broader sample of industries and retail classes to address this critical question. Not only do our measures have strong theoretical grounding in the industrial organization, finance and accounting literature, they incorporate in them the impact of actions that have been commonly cited as illustrations of a power shift. Our analysis of 14 consumer good industries shows that only a few of them exhibit a shift in market power towards retailers. Further this apparent shift is highly influenced by a small number of retailers within a single retail class.

The ideal of a system in which market values alone control, is impossible of realization because goods always move through a power structure and not through the neutral type of facility which may be suggested by the term "marketing channel."

-Wroe Alderson (1955)

At no time has the balance of power between manufacturers and retailers received more attention than in recent years. Beginning with articles in the business press, statements about a shift in power from manufacturers to the trade have slowly but surely made their way into the academic literature as well (see Alpert, Kamins and Graham, 1992; Chu, 1992; Buzzell,

Kusum L. Ailawadi, Amos Tuck School of Business Administration, Dartmouth College, 100 Tuck Hall, Hanover, NH 03755. Norm Borin, California Polytechnic and State University, Department of Business Administration, San Luis Obispo, CA 93407. Paul W. Farris, Darden School of Business Administration, University of Virginia, P.O. Box 6550, Charlottesville, VA 22906-6550. 
Quelch and Salmon, 1990; Olver and Farris, 1989 for some examples). Increasing retailer concentration, access to scanner technology, eroding brand loyalty due to increases in price promotions and private labels are the commonly mentioned causes of the rise in retailer power relative to manufacturers. However, concrete empirical evidence in support of this purported power shift has not been provided. In fact, two recent empirical studies of the food industry (Farris and Ailawadi, 1992; Messinger and Narasimhan, 1995) and one analytical paper (Kim and Staelin, 1994) have raised questions about whether this power shift has really occurred. Neither empirical study was able to verify the shift of market power through analyses of changes in profitability. Has the entire marketing community been operating under a serious misconception, or are the studies that have questioned the power shift flawed? It would seem that the answer to this question is critical for both academics and practitioners.

Three major objections can be raised about these studies that deserve further investigation. The first is that they used the wrong measure of profitability. Accounting rates of return, such as those analyzed by these authors, have historically been criticized as weak indicators of "true" economic profit. The second is that profit alone, however measured, is an incomplete measure of power. Although profit is a commonly used indicator of market power in the economic and industrial organization literature, market power may not be immediately reflected in profitability. Further, while profitability is a well-accepted indicator of market power in the economic and industrial organization literature, the behavioral view of power has traditionally been different. Third, many major shifts have been occurring outside traditional supermarket channels that may make supermarkets a poor barometer for broader trends in retailing. For example, Wal-Mart is not a part of the supermarket sample, but it is clearly one of the firms that is most often cited as an example of the power shift. In fact, measures of power which do not show increases for this company would lack face validity in the view of most marketers.

A broader sample and better measures are needed to address these issues. In this paper we:

1. discuss some of the shortcomings of using accounting rates of return such ROS and ROA as indicators of market power;

2. distinguish between exercised and potential power, integrating the behavioral and economic views of power into our conceptual framework;

3. use measures with a strong theoretical base in the industrial organization, finance and accounting literature, that have recently gained prominence in the business press, to assess both exercised and potential power; and

4. examine trends in these measures and other relevant variables for a wide variety of consumer goods industries and different retail classes.

\section{MARKET POWER AND PERFORMANCE: THE THEORETICAL FOUNDATION}

Transactions between two operating systems always involve the two factors of economic values and the balance of power. 
In this section, we briefly review some key concepts from the behavioral channels literature and economic theory that are relevant to our work on the market power of manufacturers versus retailers. Our objective is to integrate the two views to the extent possible and utilize them in the development of our measures, while also pointing out the main differences.

\section{Power and Economic Theory}

The relative power of the retailing and manufacturing stages determines the distribution of rents between stages.

-Porter (1974)

In industrial organization theory, the use of profit to assess market power dates back to Lerner's original measure of monopoly power (1934)-the long-term difference between price and marginal cost, as a ratio of price, called the Price-Cost Margin. This relationship between market power and profit has been formalized in the well-known Structure-Conduct-Performance paradigm, pioneered by Bain (1968). According to this paradigm, increased industry concentration (structure) permits firms within an industry to collude and decrease competition. This confers monopoly power on the firms that is evidenced or measured by their high economic profit rates. Although industrial organization research has evolved from a search for empirical regularities in cross-industry studies to industry-specific models where the regularities can be tested, over the past decade (Sutton, 1991), the basic relationship between market power and economic profit has not been questioned. This economic concept of power has also been applied to channels of distribution by several researchers (e.g., Porter, 1974; Reekie, 1975; Steiner, 1978; Albion and Farris, 1981; Grant, 1987). For instance, Porter $(1974,1976)$ argues that the rates of return obtained by manufacturers decrease as the bargaining power of retailers increases. Dickson, Schneier, Steidtmann and Farris (1994) study the balance of market power and profit between suppliers and buyers in an experimental economics framework. Economic models of channel relationships and coordination, where the balance of power is a determinant of how total channel profits are divided between channel members, are also relevant in this context (e.g., Kim and Staelin, 1994; Ingene and Parry, 1995; Chu, 1992; McGuire and Staelin, 1986; Jeuland and Shugan, 1983). To summarize the Structure-Conduct-Performance paradigm in the context of manufacturers and retailers, increased retailer power over manufacturers should be accompanied by reduced inter-retailer competition and and increase in retailer margin, while at the same time leading to higher inter-manufacturer competition and lower manufacturer margin.

In discussing available measures of the price-cost margin, Bain (1968) noted that the main difference between accounting costs and "economic" costs lies in the fact that the latter includes the value of the services of funds invested by the owners, and is measured as an interest return on owners' investment, calculated at the best net interest rate they could earn elsewhere. Thus, excess or residual profits are earned only to the extent that the accounting profit exceeds this interest rate times the value of owners' investment. 
There has been some debate over cross-sectional comparisons of accounting rates of return. Some researchers have noted that these returns may suffer from differences in accounting practice and other firm specific biases that we are unable to observe or even predict the direction of (Fisher and McGowan, 1983; Benston, 1985). Unfortunately, these authors do not provide a solution to the problem, and the debate over the extent to which accounting profits can be used as indicators of economic profit continues (see Martin, 1984; Long and Ravenscraft, 1984 for opposing arguments). We note two important points in this connection. First, the fact that some measure of profit is a valid indicator of market power is not at issue. Second, firm specific biases in accounting returns that affect crosssectional studies are not a concern in time series trends at the aggregate industry level. In fact, examining changes over time is a commonly used approach to econometrically control for firm-specific biases (see, for example, Boulding and Staelin, 1990). Even in the unlikely event that there are systematic differences between the accounting practices of manufacturers and retailers in each of the industries we examine, the time trends of their relative profitability cannot be affected, and certainly not reversed.

For the purposes of our work, the major conclusions that we draw from this literature are:

1. As the market power enjoyed by a channel member, relative to another, increases, one would expect its relative economic profit to also increase.

2. Accounting rates of return ignore an important component of a company's cost structure, the cost of its invested capital. The effectiveness with which a company employs its capital must enter into an evaluation of its profitability.

\section{Power and Behavioral Theory}

Power refers to the ability of one channel member to induce another channel member to change its behavior in favor of the objectives of the channel member exerting influence.

-Wilemon (1972)

There is a large literature in marketing on the definition, dimensions, bases and measurement of power in channels of distribution. Although it is not our intent to provide a comprehensive review of this literature, we present a brief discussion of some key issues which are relevant to the development of our measures of retailer versus manufacturer market power.

The theoretical foundations for much of the work on channel power lie in the original work on power by researchers like French and Raven (1959) and Emerson (1962). French and Raven provided a typology of five bases of power while Emerson's dependence framework suggests that the dependence of one party in a dyad provides the basis for the power of another, and incorporates all the bases of power within it.

El-Ansary and Stern (1972) provided a definition of power which continues to be widely accepted in the channels literature: "The ability of a channel member to control the decision variables in the marketing strategy of another member in a given channel at a different level of distribution"(p. 47). As is clear from this definition, the channels litera- 
TABLE 1

\begin{tabular}{|c|c|c|}
\hline Envirommental Changes & Bases of Power & Means of Exercising Power \\
\hline Store Concentration & Reward, Coercion & $\begin{array}{l}\text { Pricing } \\
\text { Allowances } \\
\text { Ordering Schedule } \\
\text { Delivery }\end{array}$ \\
\hline Scanner Data & Expert, Reference & $\begin{array}{l}\text { Inventory } \\
\text { Product Assortment } \\
\text { Shelf Space Allocation }\end{array}$ \\
\hline Store Loyalty & Legitimacy & $\begin{array}{l}\text { Credit } \\
\text { Private Labels } \\
\text { Training }\end{array}$ \\
\hline
\end{tabular}

ture examines channel power at the firm-level dyad (individual supplier versus channel member), and is best suited to empirical tests of firm-level hypotheses, although its implications may be extended to industry-level analyses as well.

El-Ansary and Stern also developed a comprehensive measure of channel power for such firm-level empirical analyses. The measures assess control over 13 marketing strategy variables: inventory policy, order size, pricing, sales promotion, cooperative advertising, distribution policies (e.g., selective versus extensive), delivery, credit, quality of installation work, salesmen's training, sales meetings, service schools, and participation in the activities of professional associations. Although the specific measures were weak, as is to be expected of early attempts at operationalization, they link the bases and definition of power to its application and form the foundation for subsequent work on channel power measurement. As we will see in the next section, these measures enable us to relate the exercise of power to economic goals. Similarly, Gaski's (1988) operationalization of power encompassed five activities performed by the channel members-pricing, ordering schedule, inventory, product assortment, and customer service. He too measures power as the extent to which one channel member can influence another's actions in the realm of these activities. Messinger and Narasimhan (1995) have framed the environmental changes that are often cited to support the contention that retailer power is increasing in the context of French and Raven's bases of power. Table 1 combines these with El-Ansary and Stern's measures of exercised power.

In recent years, Emerson's (1962) dependence approach has received a lot of emphasis. His framework views power as a potential influence, and is the basis for much of the work on potential or unexercised power in the channels literature (Frazier, 1983; Gaski and Nevin, 1985).

The role of relative performance of the dyad members in this literature has been rather limited. In examining performance, channels researchers have concerned itself more with channel performance from the perspective of the manufacturer than the retailer. In other words, it examines how well the channel contributes to the performance/profitability of the supplier (Gaski, 1984; Gaski and Nevin, 1985; El-Ansary and Stern, 1992; Kumar, Stern and Achrol, 1992). Further, profitability is viewed as an "outcome" of the cultivation and 
use of power (Frazier and Summers, 1984; Boyle, Dwyer, Robicheaux and Simpson, 1992), but not as an indicator of power.

\section{Behavioral Versus Economic Theory: Bridging the Gap}

The abovc discussion highlights some key differences between the economic and behavioral views: (1) the aggregate, industry level focus of the former versus the dyadic, firmlevel focus of the latter; (2) the difference between exercised and potential power; (3) the appropriateness of profit as an indicator of market power. We discuss each issue below.

\section{Firm Versus Industry Level Analyses}

Both firm-level dyadic analyses and more aggregate industry-level analyses make important contributions to the literature. The issue is not which is better, but which is more appropriate for testing the specific hypotheses in a given study. Thus, we view this not as a disagreement between the two streams of literature but as a difference in emphases. Our concern in this study is with the alleged shift in market power from manufacturers, in general, to retailers, in general, not with specific pairs of firms. Consequently, we conduct an industry level analysis. Dyadic aspects of the power balance between individual pairs of firms will certainly provide valuable insights about specific firms, but such an examination is outside the scope of our study.

\section{Exercised Versus Unexercised Power}

As noted above, the channels literature makes an important distinction between potential power and exercised power. In contrast, economic theory implicitly concerns itself only with exercised power and its consequences. In fact, the only reference to this issue that we were able to find appears in the original work of Lerner: "The unused monopoly power will be there, but being unknown and unused it is, economically, as if it were not there. For practical purposes, we must read monopoly power not as potential monopoly, but as monopoly in force"'(p. 170). We believe it is important to distinguish between potential and unexercised power and return to this issue in the next section.

\section{Profit and Market Power}

This leads us to the third point of departure between the two views-the adequacy of profitability as an indicator of market power. Clearly, economic theory views profitability, appropriately measured, as an indicator of market power. However, as noted above, we need measures of both exercised and potential market power. Current profitability is clearly not a suitable measure of potential power-another measure is needed. Whether current profitability is a good measure of exercised power depends upon how well it captures the means through which power is applied. These issues play a central role in the next 
section, where we develop measures of both exercised and potential power for our industry-level analysis.

\section{Assessing Exercised Market Power}

Since the initial work by Bain nearly thirty years ago, the cost of capital has been widely incorporated into the literature, especially in finance and accounting. Some recent examples of research addressing this issue include Feltham and Ohlson (1994), Megna and Mueller (1991), Grabowski and Vernon (1990), Ohlson (1994), Gitman and Mercurio (1982), Grabowski and Mueller (1978). Much more recently, the importance of estimating the cost of capital invested to generate accounting profits has also been recognized by practitioners and the business press (Stewart, 1991; Tully, 1993; Coca Cola Co. Annual Report, 1993).

As a result, there is now widespread agreement in both the academic literature and industry that subtracting the cost of capital employed from accounting profit provides a better measure of "true profitability". This is termed economic, residual, or abnormal profit in the academic literature and Economic Value Added (EVA) in the business press. Studies of performance in the marketing literature have not caught up with the importance of the cost of capital, however, and the two studies by Farris and Ailawadi (1992) and Messinger and Narasimhan (1995) that have examined the retail power shift in the food industry are no exception.

We believe that it is particularly important and useful to include the cost of capital in an evaluation of market power of manufacturers versus retailers. Capital includes equipment, real estate etc., which is expected to be productive long after it is purchased, as well as working capital in cash, inventories, receivables etc. Several of the phenomena that have been cited as evidence of retailers' growing power affect components of capital. For instance, the concept of residual profit or EVA is especially consistent with many of the innovations in supply chain management that focus on the reduction and inter-channel shift in inventory-carrying costs and other forms of working capital. Retailers are very concerned about the amount of capital tied up in the products they sell. Two measures of retail productivity that are increasing in popularity reflect this concern. The first is Gross Margin Return on Inventory Investment (GMROI), the importance of inventory in which is selfexplanatory. The second is Direct Product Profitability (DPP), which deducts from gross margin several costs incurred in the distribution process, including a charge for inventory holding. Further, Toys R Us and Wal-Mart have asked for suppliers to provide more goods on a consignment basis, a phenomenon that has been cited as one of the indicators of an increase in retailer power. In fact, a focus on lowering the cost of capital is said to be driving many new initiatives in the food industry, such as Efficient Consumer Response (ECR), which are designed to reduce inventory and lower transactions costs (Sansolo, 1993). According to a recent article (Tully, 1993) on the importance of EVA to business, "[Tradeloading] damages long-term returns. An important reason is that it demands so much capital. Pumping up sales requires many warehouses (capital) to hold vast temporary inventories (more capital).... It took EVA to spotlight the problem" (p. 48). 


\section{TABLE 2}

Components of Economic Value Added

\begin{tabular}{|c|c|c|}
\hline Elements & Calculation & Measure \\
\hline Sales (S) & $\underline{s-\operatorname{coGs}}$ & Gross Margin \\
\hline Cost of Goods Sold (COGS) & $\mathrm{S}$ & $(\mathrm{GM} / \mathrm{S})$ \\
\hline Operating Costs (OC) & $\frac{S-\text { COGS -OC }}{S}$ & $\begin{array}{l}\text { Return on Sales } \\
\text { (ROS) }\end{array}$ \\
\hline Invested Capital (IC) & $\frac{S-\operatorname{COCS}-O C}{\mathrm{IC}}$ & $\begin{array}{l}\text { Return on Investment } \\
\text { (ROI) }\end{array}$ \\
\hline Total Assets (TA) & $\frac{S \operatorname{COGS} O C}{T A}$ & $\begin{array}{l}\text { Return on Asscts } \\
(\text { ROA })\end{array}$ \\
\hline Cost of Capital (CC) & $\begin{array}{l}S-C O G S-O C-C C \\
\frac{S-C O G S-O C-C C}{S}\end{array}$ & $\begin{array}{c}\text { Economic Value Added } \\
\text { (EVA) } \\
\text { EVA/Sales } \\
\text { (EVA/S) }\end{array}$ \\
\hline
\end{tabular}

Thus, the explicit incorporation of the cost of capital in EVA has two advantages. First, it counters a major drawback in accounting rates of return as indicators of economic profit, noted by researchers. Second, it integrates the economic and behavioral literature since it is directly influenced by some of the means through which retailers can exercise their alleged power. Thus, it is a more complete indicator of whether or not market power has shifted towards retailers. Table 2 depicts the costs components that are captured by each of the traditional accounting measures and EVA.

\section{Assessing Potential Market Power}

EVA captures the historical application of power better than traditional rates of return. However, there is also the question of whether power is being accumulated but not immediately exercised, in order to preserve it for the future. Why might retailers not want to use their power to increase profitability? One answer may lie in Alderson's "power principle", which suggests that the action chosen in the current situation should be such as to broaden freedom of choice in the future and avoid the risk of losing power by pushing it too far.

Professor Raymond Corey, in a conversation with one of the authors, captured this in his statement that "if you use power, you use it up." It might be that retailers are not exercising power in the short term so as not to "use it up". One example of such a strategy is that retailers sometimes nurture small brands. The leading brands have more distribution, and, consequently, their advertising is more efficient. Increased distribution can also cause inter-retailer price competition, making the brand more attractive to consumers. Over time, some retailers may try to escape the intense price pressure typical of widely distributed brands by trying to nurture private labels or smaller competitive brands. For instance, some building supply companies favored Makita power tools over Black \& Decker products when the latter were available in too many outlets. By nurturing small brands, over whom 
they presumably have the greatest power, retailers may be able to preserve future alternatives versus large, more powerful brands.

It may also be that retailers such as Wal-Mart, who almost everybody agrees are indeed gaining power, are strong marketing strategists who invest in growth for long-term success, and the results of their choice may become fully apparent in future rather than contemporaneous monetary returns. In other words, while exercised market power is reflected in achieved EVA, unexercised market power increases the potential for future EVA. Fortunately, a measure of the potential for future EVA is also available in the finance and accounting literature. We discuss it below.

There is a growing stream of financial accounting literature which reveals the relationship between expected future EVA and market value. The classical dividend capitalization model equates market value to the discounted present value of the expected dividend stream (Williams, 1938). In recent years, researchers have drawn on this model to develop the relationship between market value and expected profit in the future, as well as between market value and expected residual earnings or EVA in the future (see Stickney, 1995 for a good overview). Peasnell $(1981,1982)$ shows that, as long as the Clean Surplus Relation (CSR) in accounting holds, the difference between the market value of a firm and its book value is equal to the present value of future expected EVA of the firm. ${ }^{1}$ Recent theoretical models of market valuation based upon accounting information, by researchers like Ohlson (1994), Feltham and Ohlson (1994), and Fairfield (1994), further build upon this work. The difference between market and book value is termed "goodwill" in the literature (Peasnell, 1981, Ohlson, 1994), and has recently begun to receive attention in the business press under the name Market Value Added or MVA (Stewart, 1991; Walbert, 1993). Thus: ${ }^{2}$

$$
\begin{aligned}
{\text { Market Value } \text { Added }_{t}}=\text { Market Value }_{t}-\text { Book Value }_{t} \\
=\sum_{t=1}^{t=T E V A_{t}} \frac{(1+r)^{t}}{\text { where } r}=\text { Discount Rate }
\end{aligned}
$$

MVA serves as an indicator of market power which is being accumulated for future earnings. If retailers have indeed been increasing their market power and therefore their ability to increase EVA in the future, then efficient capital markets should recognize this potential for future earnings and market participants should incorporate this knowledge in their valuation of retailers. Thus, we expect an increase in market power which may not have been exercised yet, but holds the potential for future increases in EVA, to be reflected in higher MVA.

Two points deserve mention about MVA. The first is its advantage over ratio measures such as Market/Book ratios in that it represents the amount of wealth that a firm is expected to create. Thus, firms that grow their investments effectively for future EVA (e.g., WalMart) will have higher MVAs while their Market/Book ratios stay steady or even decline. Of course, growth per se should not and does not increase MVA. If additional capital invested by the firm does not bring future earnings in excess of the cost of the capital (i.e., positive future EVA), then the market value of that capital will be equal to its book value (Stewart, 1991; Stickney, 1995). Consequently, MVA will remain unchanged. In other 
words, growth in investments will increase MVA only if the investments are effectively made in that they are expected to bring positive future EVA.

The second point is a caveat which recognizes that the market efficiency hypothesis is controversial. Of the three forms of the market efficiency hypothesis, the weak-form (which states that capital markets fully incorporate the information in past stock prices) and semi-strong form (which says that capital markets fully incorporate all publicly available information) have plenty of empirical support. The strong form (which states that all information is incorporated, public or private) does not seem to be widely substantiated by empirical evidence (Ross, Westerfield and Jaffe, 1993). Information about market power of retailers versus manufacturers can be considered public thus making the less questionable semistrong form applicable. However, as noted by a reviewer, it is possible for market participants to be influenced by "street talk" about the power shift. It is important to bear this caveat in mind.

\section{Summary: Market Power and Performance}

In this section, we have provided an overview of the channels and economic literature on the subject of power and attempted to integrate them in our conceptual framework and the development of our measures. Economic Value Added is a measure of historical performance which reflects exercised power more completely than do accounting rates of return. Market Value Added is a forward-looking measure that assesses EVA expected in the future as a result of potential power that may not yet have been exercised.

Table 3 summarizes this discussion by integrating the marketing strategy variables through which retailers can accumulate and exercise power (see Stern and El-Ansary, 1972; Gaski, 1988) with the corresponding components of EVA and MVA on which they would have the biggest impact. For instance, retailers can wield their power over manufacturers by negotiating lower prices and trade allowances from them, the impact of which should be seen in relative Gross Margins and Advertising \& Promotion expenses. They should be able to reduce their inventory and administrative costs either by transferring them to manufacturers or by reducing total system costs through better information use and category management and techniques such as JIT etc. ${ }^{3}$ The extent to which they are able to differentiate themselves through better informed and skilled managers and successful private labeling should improve their future profit making potential, and therefore their market value.

\section{MEASUREMENT OF VARIABLES FOR EMPIRICAL ANALYSIS}

We use financial data for the period 1982-1992 from the COMPUSTAT and University of Chicago CRSP databases for our empirical analyses. The Standard Industry Classification coding manual was used to categorize companies with specific SIC codes into various 


\section{TABLE 3}

\section{The Performance Impact of Marketing Activities}

\begin{tabular}{lll}
\hline \multicolumn{1}{c}{ Marketing Activities } & Affected Components & \multicolumn{1}{c}{ Expected Impact of Relative Market Power } \\
\hline Pricing & Gross Margin/Sales & Retailers should negotiate lower prices from manufac- \\
Private labels & turers, thus increasing their GM/S, but only if they do \\
& not correspondingly lower their selling prices (which \\
& some retailers do as a deliberate competitive strategy). \\
& Private labels should also increase retailer gross mar- \\
& gins.
\end{tabular}

Allowances

Ordering Schedule

Delivery

Shelf Space

Inventory

Product Assortment

(Category Mgmt)

Credit

Training

Scanner Information

Private Labels
Advertising \& Promotion/ Sales

SG\&A/Sales

ROS

Inventory/Sales

ROA

EVA

Management Skills

Stock Price

MVA
Retailers should negotiate increased trade allowances from manufacturers, thus increasing manufacturer $A \& P / S$.

Retailers should negotiate more favorable terms that transfer such administrative overheads to manufacturers, thus decreasing their SG\&A/S and increasing their ROS.

Retailers should either transfer inventory carrying costs to manufacturers, thus decreasing their $1 / \mathrm{S}$, or systems like EDI, JIT etc. should reduce total system costs, decreasing $\mathrm{l} / \mathrm{S}$ for both manufacturers and retailers.

Retailers should negotiate more favorable credit terms which reduce their administrative costs and reduce their cost of working capital, thus increasing EVA.

Better training and improved information systems should improve management skill, thus increasing the potential of retailers for long term profitability, and therefore higher MVA. Successful private labels should reduce dependence on manufacturers and increase potential for future profit.

industries. Our sample contains 909 manufacturers and 274 retailers. Table A-1 in the appendix lists the SICs included in each industry.

Along with EVA and MVA, we also analyze Gross Margin/Sales (GM/S), Advertising \& Promotion/Sales (A\&P/S), Selling, General \& Administrative Expenses/Sales (SG\&A/ S), Return on Sales (ROS), Return on Assets (ROA), Return on Investment (ROI) and Inventory/Sales (I/S). As shown in Table 1, some of these variables are logically prior components of the others. For example, a measure like EVA/Sales is calculated as GM/S minus various operating costs like SG\&A/S and A\&P/S, and a charge for capital, one component of which is Inventory. Therefore, examining the components and the composite measures is more informative than only considering trends in, say, EVA and MVA. EVA/S might exhibit a decreasing trend because GM/S decreased and the other cost components did not decrease enough to offset the loss of margin, or it might increase due to higher operating costs, despite an increase in GM/S. Trends in components help us understand which of these and other alternative explanations is valid. This is particularly important in the context of our analysis since giant retailers like Wal-Mart are said to be lowering their selling prices and therefore their gross margins as a deliberate strategy, while keeping their operating costs low. Simi- 
larly, the components can show the full impact of increased sales promotion both in the potential lowering of manufacturer gross margins vis a vis retailers and the potential increase in the retailer's cost of inventory due to forward buying. Thus, we examine trends in the mean values of all these variables for retailers and manufacturers in each industry. Means of all the ratio variables are weighted by their denominator. Thus, variables like GM/S, A\&P/S, and ROS are weighted by Sales, ROA is weighted by Assets and ROI is weighted by Investment.

\section{Measurement of Economic and Market Value Added}

While all other variables are self-explanatory, our measures of EVA and MVA require explanation.

\section{Economic Valued Added}

Capital consists of two parts, debt and equity. The cost of debt (both long term and short term) is approximated by interest expense adjusted for its tax deductibility. ${ }^{4}$ We use the Capital Asset Pricing Model to obtain the risk adjusted rate at which cost of equity must be calculated: 5

$$
r=\text { Risk Free Rate }+\beta(\text { Average Stock Return }- \text { Risk Free Rate })
$$

An annual "beginning of year" $\beta$ is calculated for each COMPUSTAT firm in our sample for which monthly stock returns are available on the CRSP database for at least the previous three years. Five years of data are used where available. $B$ for the $i^{\prime}$ th firm in the $t^{\prime}$ th year is estimated as:

$$
\beta_{i t}=\frac{\text { covariance }\left(R_{i}, R_{m}\right)}{\text { variance }\left(R_{m}\right)}
$$

where $R_{i}$ represents the monthly returns for the i'th firm over the previous 3-5 years and $R_{m}$ represents the monthly return for the market as a whole over the same time period. For firms whose $\beta$ is not available, we use the average of the industry and channel to which that firm belongs.

We use the average return on the 1-year Treasury Bill as the risk-free rate for our analysis of yearly data. Since the intermediate term equity risk premium is approximately $7.5 \%$ (SBBI 1994 Yearbook, Ibbotson Associates), Equation 1 simplifies to:

$$
r=1 \text { Year T.Bill Rate }+\beta(7.5 \%)
$$

The cost of equity is simply the book value of common equity times this rate " $r$ ". EVA is calculated as Net Income After Interest Expense and Taxes but before Extraordinary Items minus the above Cost of Equity. 


\section{Market Value Added}

The calculation of MVA is relatively straightforward:

$$
\text { MVA = Market Value of Equity }- \text { Book Value of Equity }
$$

The market value of equity is calculated as the product of share price at the close of each fiscal year and the number of common shares outstanding at that time.

\section{Dollar and Ratio Measures}

Note that we use two EVA based measures in our analysis-Dollar EVA and EVA as a percentage of Sales. The latter corrects ROS for the cost of capital, while preserving its ratio view. However, Dollar EVA provides us with information about the "value" being created by a firm, that the ratios may obscure. For example, consider that it is quite possible for a company whose sales are falling every year and that has almost been forced out of the market, to have a rate of return that: (1) stays steady over time; and (2) is comparable to that of a high-growth competitor with a major share of the market. On the other hand, Dollar EVA for the two companies would be quite different as would its value for the dying company over time. We believe that important as ratios are, it is also important to be able to distinguish between scenarios such as the two described above. Similarly, ratios may not fairly represent the effectiveness of companies that are investing strongly in growth and therefore have stable or even declining profit ratios. Trends in the Dollar EVA of such companies will show whether their investments have been wisely made in that they earn more than the cost of the capital invested.

\section{RESULTS}

In this section, we present the results of our empirical analysis starting with an aggregate view of all manufacturers vis a vis all retailers, across these industries. Table 4 presents trend regression coefficients for several of our performance measures, while Figures 1 and 2 depict relative trends in EVA and MVA for manufacturers and retailers. Recall that all ratio measures are weighted by their denominator.

The data suggest that retailers are not significantly better off compared to manufacturers on any of the performance measures. Retailer EVA and MVA have increased at a significantly slower rate than manufacturers. These results certainly do not support the contention that retailers, in general, have increased their power relative to manufacturers.

Of course, such an aggregate view may hide differences across industries and retail classes. We now examine individual industries and retail classes. Our findings, discussed below, provide interesting insights that are not available from an analysis of only a single industry (Farris and Ailawadi, 1992; Messinger and Narasimhan, 1995). ${ }^{6}$ 


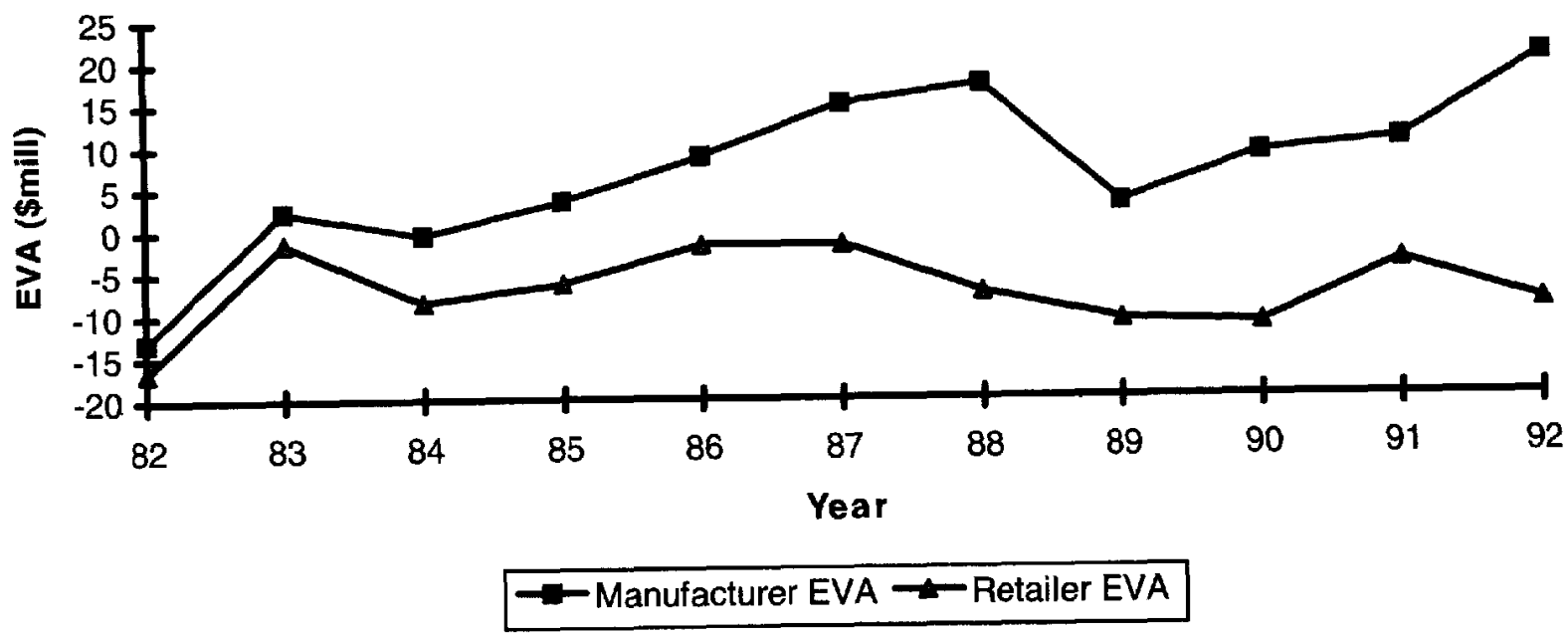

Figure 1. EVA for Entire Sample 


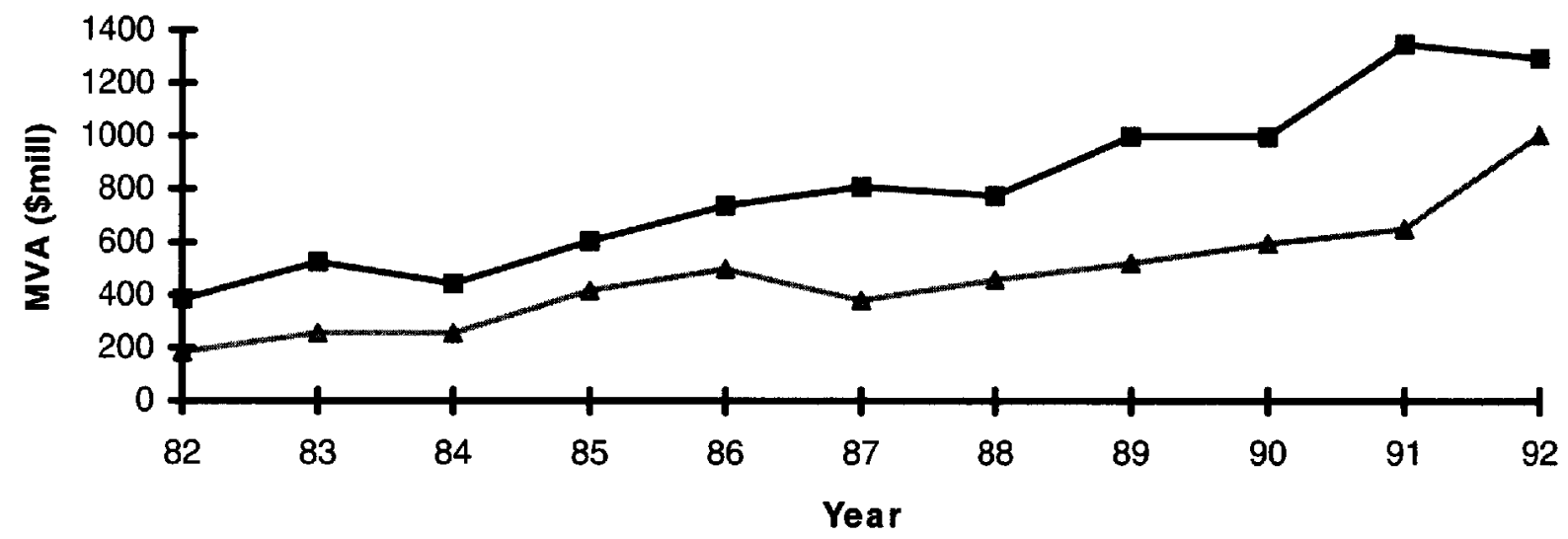

$\rightarrow-$ Manufacturer MVA $\rightarrow$ Retailer MVA

Figure 2. MVA for Entire Sample 


\section{TABLE 4}

Trend Regression Coefficients for Entire Sample (1982-1992)

\begin{tabular}{lcc}
\hline \multicolumn{1}{c}{ Measure } & All Manufacturers & All Retailers \\
\hline Gross Margin/Sales (GM/S \%) & $0.60^{*}$ & $-0.06^{* *}$ \\
Return on Sales (ROS \%) & $(0.09)$ & $(0.04)$ \\
& $-0.08^{*}$ & $-0.13^{*}$ \\
Return on Assets (ROA \%) & $(0.04)$ & $(0.02)$ \\
Return on Investment (ROI \%) & $-0.30^{*}$ & $-0.28^{*}$ \\
& $(0.04)$ & $(0.04)$ \\
Economic Value Added (EVA \$mill) & $-0.34^{*}$ & $-0.47^{*}$ \\
& $(0.07)$ & $(0.08)$ \\
ElA/Sales (EVA/5 \%) & $2.14^{*}$ & -0.06 \\
& $(0.61)$ & $(0.42)$ \\
Market Value Added (MVA \$mill) & $0.13^{*}$ & 0.00 \\
& $(0.04)$ & $(0.03)$ \\
Inventory/Sales (I/S \%) & $94.34^{*}$ & $38.14^{*}$ \\
& $(8.44)$ & $(5.89)$ \\
SG\&A/Sales (SGiA/S \%) & $-0.32^{*}$ & 0.03 \\
& $(0.06)$ & $(0.06)$ \\
Advtg \& Promotion/Sales (A\&P/S \%) & $0.46^{*}$ & -0.02 \\
& $(0.08)$ & $(0.03)$ \\
& $-0.10^{* *}$ & $-0.04^{*}$ \\
Not Standad & $(0.05)$ & $(0.01)$ \\
\hline
\end{tabular}

Notes: Standard etrors are in parentheses

Significant at $p=0.05 ; \quad$ Significant at $p=0.10$

TABLE 5

Trend Regression Coefficients for Food Industry (1982-1992)

\begin{tabular}{lcc}
\hline \multicolumn{1}{c}{ Measure } & Manufacturers & Retailers \\
\hline Gross Margin/Sales (GM/S \%) & $1.03^{*}$ & $0.24^{*}$ \\
& $(0.22)$ & $(0.03)$ \\
Return on Sales (ROS \%) & $0.15^{*}$ & $-0.12^{*}$ \\
& $(0.02)$ & $(0.03)$ \\
Return on Assets (ROA \%) & -0.01 & $-0.57^{*}$ \\
& $(0.04)$ & $(0.12)$ \\
Return on Investment (ROI \%) & 0.05 & $-0.92^{*}$ \\
& $(0.07)$ & $(0.19)$ \\
Economic Value Added (EVA \$mill) & $9.11^{*}$ & -0.12 \\
& $(1.47)$ & $(0.83)$ \\
EVA/Sales (EVA/S \%) & $0.27^{*}$ & -0.00 \\
& $(0.06)$ & $(0.02)$ \\
Market Value Added (MVA \$mill) & $252.73^{*}$ & $60.04^{*}$ \\
& $(20.69)$ & $(12.34)$ \\
Inventory/Sales (I/S \%) & $-0.40^{*}$ & 0.01 \\
& $(0.04)$ & $(0.03)$ \\
SG\&A/Sales (SGAS \%) & $0.71^{*}$ & $0.10^{*}$ \\
Advtg \& Promotion/Sales (A\&P/S \%) & $(0.21)$ & $(0.35)$ \\
& -0.03 & $-0.02^{*}$ \\
\hline
\end{tabular}

Notes: Standard errors are in parentheses

* Significant at $p=0.05 ;{ }^{* *}$ Significant at $p=0.10$ 


\section{Analysis of the Food Industry}

First, we present results for the food industry, which has been analyzed by both Farris and Ailawadi (1992) and Messinger and Narasimhan (1995). Table 5 summarizes trends for food manufacturers and grocery retailers.

Our analysis validates the results reported by the earlier studies for Gross Margin, ROS, ROA and ROI. These traditional rates of return have either increased significantly or remained stable for manufacturers, whereas they have either increased at a much slower rate (e.g. Gross Margin/Sales), or declined significantly for retailers.

As shown in Figures 3 and 4, accounting for the cost of capital does not reverse the trends reported by the previous two studies, and nor does an examination of their potential for future earnings. Food manufacturers have been able to improve their EVA at the rate of approximately $\$ 9$ million per year, while EVA for grocery retailers has shown no change. Similarly, food manufacturers have increased their goodwill at the rate of $\$ 253$ million per year while the corresponding rate for grocery retailers is only $\$ 60$ million per year. We find no evidence for an increase in the power exercised or accumulated for the future, by grocery retailers.

The data also show that although food retailers have held their inventory/sales ratio fairly steady or increased it slightly, food manufacturers have done better-their inventory/sales ratios have significantly decreased. One of the strategies employed by manufacturers to increase their EVA has been the reduction of working capital tied up in inventories, whereas, contrary to widespread beliefs, food retailers appear not to have accomplished this reduction. Finally, manufacturer spending on SG\&A as a percentage of Sales has increased much faster than retailer spending, but the former's gross margins have clearly increased faster than $S G \& A / S$, in the food industry.

If performance, both present and potential, of food retailers has been declining relative to food manufacturers and this decline is not sensitive to the measure of performance used, why is the press, both business and academic, so adamant about increasing retail power? Has this shift occurred in non-food industries?

\section{Analysis of Remaining Industries}

We analyzed trends in each measure for thirteen other consumer good industries. Table 6 summarizes the key findings from this analysis. Details of the trend regression coefficients for manufacturers and retailers in each industry are provided in Table A-2 of the Appendix.

\section{Accounting Rates of Return and Economic Value Added}

Manufacturer gross margins have been improving at a rate that is significantly faster than that for retailers in all 13 industries. Retailer ROS has improved relative to manufacturer ROS only in the computer industry, where a few large manufacturers like IBM and DEC 


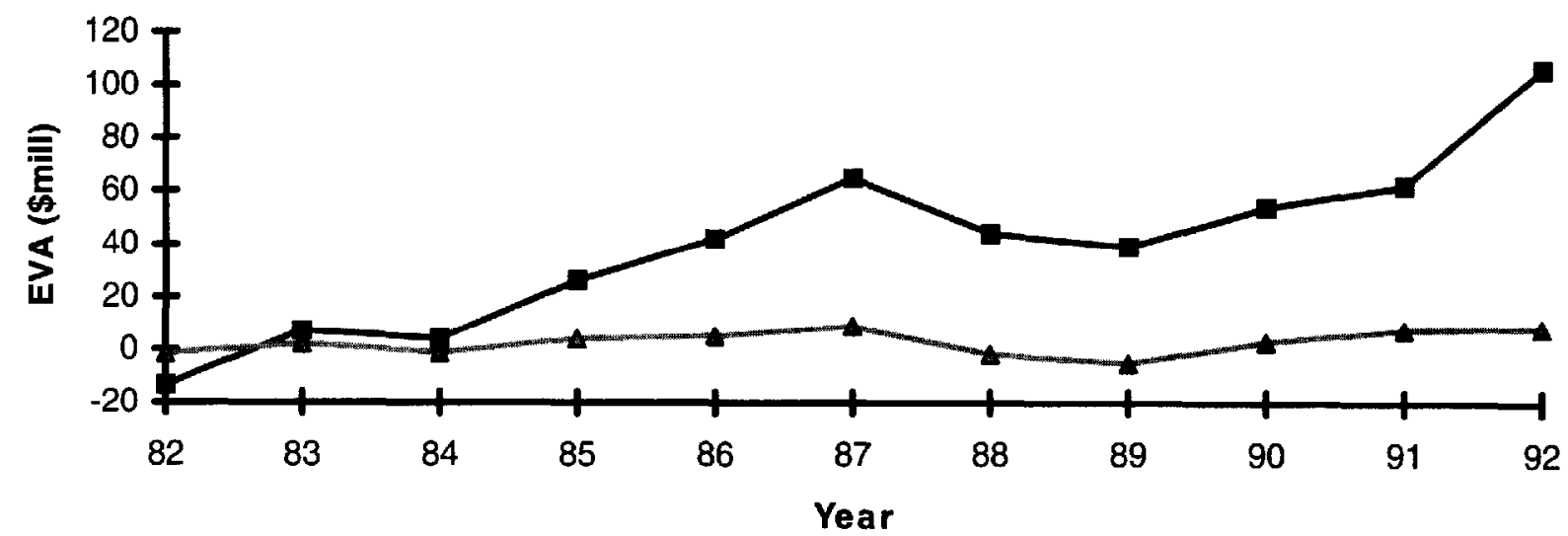

$\rightarrow$ Manufacturers - Retailers

Figure 3. EVA for Food Industry 


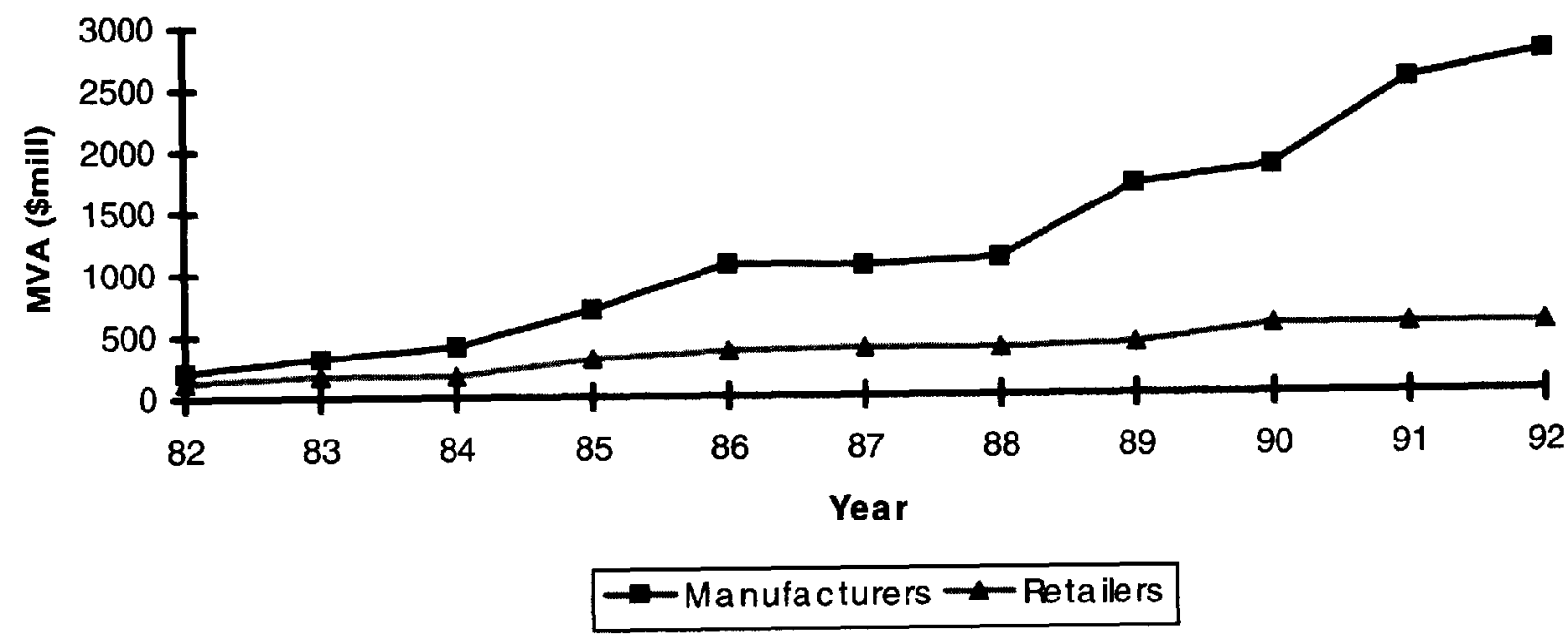

Figure 4. MVA for Food Industry 


\section{TABLE 6}

\section{MANUFACTURERS VERSUS RETAILERS: SUMMARY OF RESULTS*}

\begin{tabular}{|c|c|c|c|c|}
\hline \multirow[b]{2}{*}{ Measure } & \multicolumn{2}{|c|}{$\begin{array}{l}\text { Industries with Retailers Better off Relative to Manufacturers } \\
\qquad \text { (Total = 13) }\end{array}$} & \multicolumn{2}{|c|}{$\begin{array}{l}\text { Industries with Specialty Retailers Better off Relative to Manufacturers } \\
\qquad(\text { Total }=8)\end{array}$} \\
\hline & Number & Industries & Number & Industries \\
\hline $\mathrm{CM} / \mathrm{S}$ & 0 & & 0 & \\
\hline ROS & 1 & Computers & 0 & \\
\hline ROA & 0 & & 2 & Appliances, Audio/Nideo \\
\hline ROI & 0 & & 0 & \\
\hline EVA & 1 & Computers & 1 & Computers \\
\hline EVA/S & 1 & Computers & 1 & Computers \\
\hline MVA & $9^{\oplus}$ & All except Appliances; Drugs; Toiletries; and Tobacco & 3 & Apparel, Computers, Toy \\
\hline $1 / 5$ & 0 & & 1 & Appliances \\
\hline SG\&A/S & 8 & $\begin{array}{l}\text { All except Appliances; Furniture; Jewelry; Office } \\
\text { Machines; and Wood }\end{array}$ & 5 & All except Appliances; Footwear; and Furniture \\
\hline$A \& P / S$ & 7 & $\begin{array}{l}\text { All except Appliances; Audio/Nideo; Drugs; Office } \\
\text { Machines; Tobacco; and Toys }\end{array}$ & 4 & $\begin{array}{l}\text { All except AudioNideo; Computers; Furniture; and } \\
\text { Toys }\end{array}$ \\
\hline
\end{tabular}

Notes: "Ceneral Merchandisers are included in the retailer sample for 9 industries.

@ Eliminating Wal-Mart from the sample reduces this number to 3 . 
have suffered. The same is true of both EVA and the ratio of EVA/Sales. The evidence is clearly not consistent with a general increase in power exercised by retailers.

\section{Market Value Added}

Interestingly, retailers perform much better on the market based measure used in our analysis. Their MVA has increased at a significantly faster rate than manufacturers in 9 of the 13 industries. It would seem that the potential power of retailers, as perceived by the market, has increased in several industries.

A closer look reveals that, except for Appliances, the remaining three industries where retailer MVA has not improved relative to manufacturers are served mainly by grocery retailers-drugs, toiletries and tobacco products. On the other hand, 8 of the 9 industries where retailer MVA has improved faster than manufacturer MVA, are served, apart from specialty retailers, by three groups of retail stores, who we refer to as General Merchandisers in the remainder of this paper: Variety (5331), General Merchandise (5399) and Department (5311) Stores.

\section{Separating Out The Effect of General Merchandisers}

There are eight industries in our sample whose products are sold both by "specialty" retailers and these general merchandisers. In order to determine the extent to which the performance of retailers is influenced by the latter, we also conducted the analyses for only the specialty retailers (excluding SICs 5311, 5331, and 5399). The last two columns of Table 6 summarize this analysis, while Table A-2 provides the detailed results for each of the eight industries. Overall, our earlier conclusions about exercised power remain unchanged. There are minor differences in some performance measures like SG\&A/S and ROA. However, the most notable difference is in MVA trends. As we suspected, conclusions about potential power, based on MVA, do depend substantially on whether or not general merchandisers are included. We find that, once general merchandisers are excluded, retailers are better off relative to manufacturers in only three industries. Clearly, general merchandisers do have a big impact on MVA trends for retailers. Clearly, the market perceives an increase in the power of certain classes of retailers but not others.

\section{A Comparison of Various Retailer Classes}

In order to get a better understanding of such differences, we now examine various classes of retailers.

Grocery Retailers versus General Merchandisers

The first comparison that is called for is between grocery retailers and general merchandisers, since it is clear that grocery retailers have not improved their position vis a vis 
manufacturers while general merchandisers have. The first two rows of Table 7 compares trends in all measures for these two classes of retailers.

Some interesting differences are apparent between the two retail classes. Grocery retailers are better off relative to general merchandisers on Gross Margin but both classes have held their EVA fairly steady. This is because general merchandisers have also reduced their Inventory/Sales, SG\&A/Sales and Advertising \& Promotion/Sales at a significantly higher rate. Further, general merchandisers have increased their MVA at an average rate of $\$ 151$ million per year, while MVA for grocery retailers has increased only at a third of that rate, at $\$ 60$ million per year. These findings suggest that: (1) general merchandisers have lowered their gross margins but have been able to survive by lowering their operating costs and costs of capital; and (2) the market perceives a higher potential for power in general merchandisers compared with the traditional supermarket channel. These findings are also consistent with the impact of general merchandisers on the MVA trends we observed for 9 industries in the previous section.

\section{Specialty Retailers versus General Merchandisers}

In recent years, some of the discussion about retailing phenomena has centered around the re-emergence of specialty retailers (Bates, 1989; Wilson, 1993). For instance, Bates predicted that the "strategic pendulum will move hack into the specialty store arena", and "the next two decades could well be dominated by new forms of specialty stores" (p. 383). We therefore examine the data to see how specialty retailers, on the whole, have fared relative to general merchandisers. The third row of Table 7 shows that, as in the previous comparison, Gross Margin has decreased faster for general merchandisers, but there is no significant difference in ROS or EVA trends between the two groups. MVA for the general class, on the other hand, has increased much faster than for the specialty retailers. Finally, although there is no significant difference in the rate at which both classes have been reducing their SG\&A/Sales and Advertising \& Promotion/Sales, specialty retailers have, unlike general merchandisers, not been able to decrease their Inventory/Sales ratios. Nor have their SG\&A/Sales ratios declined at as a high a rate. This is not surprising considering that product line assortment and service are some of the advantages that specialty stores are expected to provide.

Thus, there are significant differences between various retailer classes in terms of the market's perception of their potential power, even though exercised power, as evidenced by EVA is not very different. Before concluding that general merchandisers have increased their power relative to specialty and grocery retailers, we take a closer look at the group of general merchandisers, specifically the impact of one firm which is known to have gained power in recent years-Wal-Mart.

\section{General Merchandisers Excluding Wal-Mart}

The fourth row of Table 7 depicts trends in the general merchandiser group after excluding Wal-Mart from the sample. Although the exclusion of Wal-Mart does not have a 


\section{TABIE 7}

A Comparison of Trends for Different Retail Classes

\begin{tabular}{|c|c|c|c|c|c|c|c|c|c|c|}
\hline Retailer Class & $C M / S$ & ROS & ROA & ROI & EVA & EVAVS & MVA & I/S & SGA/S & $A \& P / S$ \\
\hline Fond & $0.24^{*}$ & $-0.12^{*}$ & $-0.57^{*}$ & $-0.92^{*}$ & -0.12 & -0.00 & $60.05^{*}$ & 0.01 & $0.10^{*}$ & -0.03 \\
\hline & $(0.03)$ & $(0.02)$ & $(0.12)$ & $(0.19)$ & $(0.83)$ & $(0.03)$ & $(12.34)$ & $(0.03)$ & $(0.03)$ & $(0.01)$ \\
\hline General Merchandisers & $\begin{array}{c}-0.38^{*} \\
(0.06)\end{array}$ & $\begin{array}{c}-0.15^{*} \\
(0.04)\end{array}$ & $\begin{array}{c}-0.22^{*} \\
(0.04)\end{array}$ & $\begin{array}{c}-0.36^{*} \\
(0.10)\end{array}$ & $\begin{array}{r}-1.93 \\
(1.68)\end{array}$ & $\begin{array}{c}-0.01 \\
(0.05)\end{array}$ & $\begin{array}{c}151.50^{*} \\
(19.96)\end{array}$ & $\begin{array}{c}-0.15 \\
(0.10)\end{array}$ & $\begin{array}{c}-0.19^{*} \\
(0.06)\end{array}$ & $\begin{array}{c}-0.08^{*} \\
(0.02)\end{array}$ \\
\hline Specialty & $\begin{array}{c}-0.01 \\
(0.09)\end{array}$ & $\begin{array}{c}-0.18^{*} \\
(0.04)\end{array}$ & $\begin{array}{c}-0.37^{*} \\
(0.07)\end{array}$ & $\begin{array}{c}-0.49^{*} \\
(0.10)\end{array}$ & $\begin{array}{c}0.07 \\
(0.15)\end{array}$ & $\begin{array}{c}0.04 \\
(0.03)\end{array}$ & $\begin{array}{c}15.29^{*} \\
(4,26)\end{array}$ & $\begin{array}{c}-0.01 \\
(0.07)\end{array}$ & $\begin{array}{c}0.11 \\
(0.07)\end{array}$ & $\begin{array}{c}-0.03^{*} \\
(0.01)\end{array}$ \\
\hline General Merchandisers & $-0.38^{*}$ & $-0.17^{*}$ & $-0.24^{*}$ & $-0.43^{*}$ & $-3.38^{*}$ & $-0.06^{* *}$ & $44.30^{*}$ & $-0.22^{* *}$ & $-0.21^{*}$ & $-0.04^{*}$ \\
\hline except Wal-Mart & $(0.07)$ & $(0.04)$ & $(0.04)$ & $(0.09)$ & $(1.28)$ & $(0.04)$ & $(11.34)$ & $(0.12)$ & $(0.06)$ & $(0.02)$ \\
\hline Wal-Mart & $\begin{array}{c}-0.68^{*} \\
(0.04)\end{array}$ & $\begin{array}{c}-0.02 \\
(0.02)\end{array}$ & $\begin{array}{c}-0.05 \\
(0.12)\end{array}$ & $\begin{array}{c}0.01 \\
(0.20)\end{array}$ & $\begin{array}{c}83.69^{*} \\
(13.00)\end{array}$ & $\begin{array}{c}0.05^{* *} \\
(0.03)\end{array}$ & $\begin{array}{c}5724.70^{*} \\
(959.36)\end{array}$ & $\begin{array}{c}0.07 \\
(0.05)\end{array}$ & $\begin{array}{c}-0.46^{*} \\
(0.05)\end{array}$ & NA \\
\hline Toys R Us & $\begin{array}{c}-0.30^{*} \\
(0.05)\end{array}$ & $\begin{array}{c}-0.06 \\
(0.04)\end{array}$ & $\begin{array}{c}-0.30^{*} \\
(0.07)\end{array}$ & $\begin{array}{c}-0.47^{*} \\
(0.13)\end{array}$ & $\begin{array}{c}5.99^{*} \\
(2.50)\end{array}$ & $\begin{array}{c}0.05 \\
(0.06)\end{array}$ & $\begin{array}{l}706.14^{*} \\
(65.29)\end{array}$ & $\begin{array}{c}0.31 \\
(0.19)\end{array}$ & $\begin{array}{c}-0.16^{*} \\
(0.06)\end{array}$ & $\begin{array}{c}-0.11^{*} \\
(0.02)\end{array}$ \\
\hline Home Depot & $\begin{array}{c}0.72 \\
(0.07)\end{array}$ & $\begin{array}{c}0.15 \\
(0.10)\end{array}$ & $\begin{array}{c}-0.00 \\
(0.36)\end{array}$ & $\begin{array}{c}-0.41 \\
(0.63)\end{array}$ & $\begin{array}{c}5.02 \\
(2.95)\end{array}$ & $\begin{array}{c}0.18 \\
(0.11)\end{array}$ & $\begin{array}{l}1416.49^{*} \\
(398.93)\end{array}$ & $\begin{array}{c}-0.77^{*} \\
(0.25)\end{array}$ & $\begin{array}{c}-0.06 \\
(0.09)\end{array}$ & $\begin{array}{c}-0.27^{*} \\
(0.04)\end{array}$ \\
\hline
\end{tabular}

Notes: Standard errors are in parentheses

Significant at $p=0.05 ; "$ " Significant at $p=0.10$ 


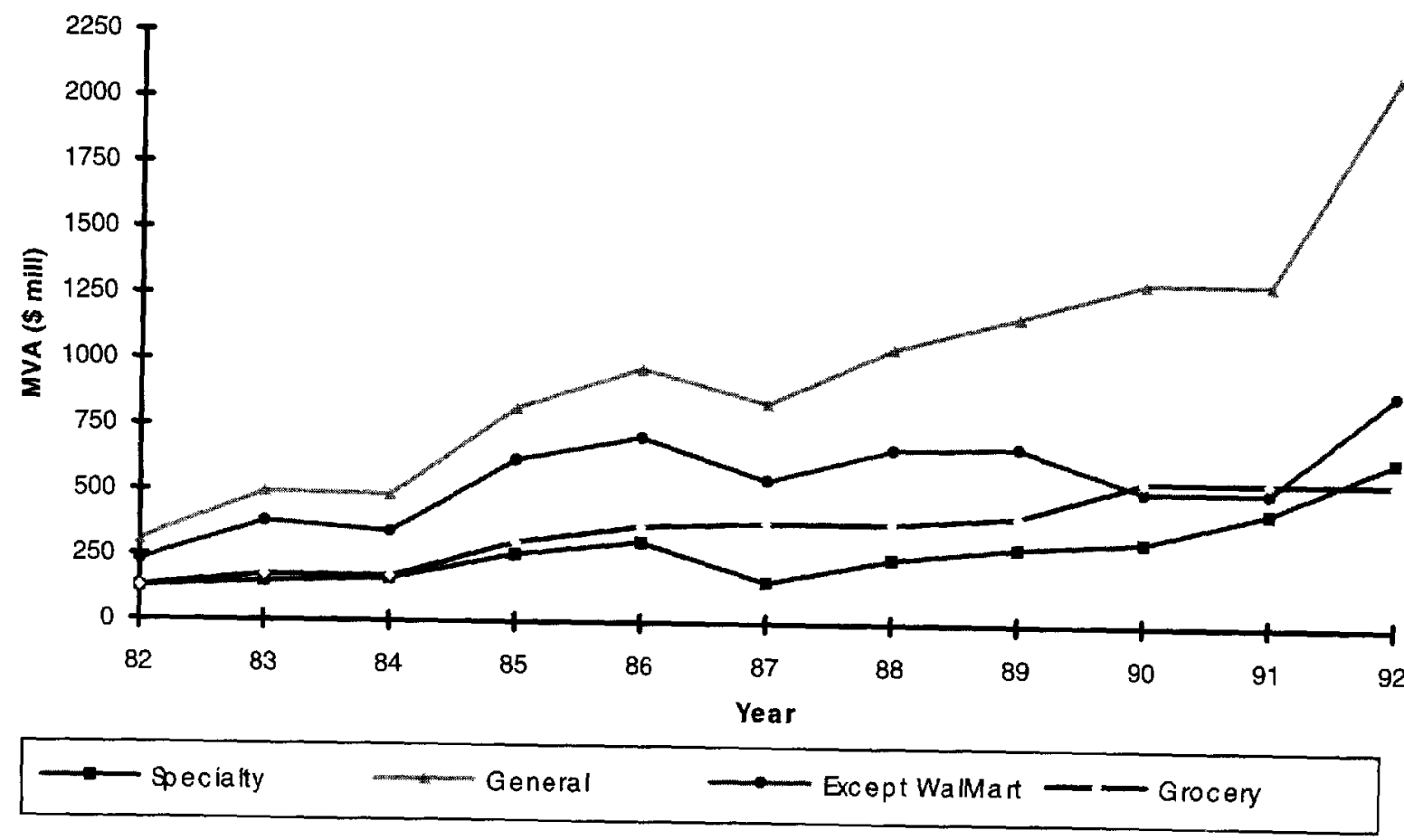

Figure 5. MVA for Different Retail Classes 
significant effect on any of the internal, historical measures, the effect on MVA trend is dramatic. MVA for this group has only increased by an average of $\$ 44$ million, which, if anything, is less than either the specialty or the grocery retailers. Figure 5 depicts the trend in MVA for each of the four groups of retailers examined in this section. We must conclude that with the exception of Wal-Mart, general merchandisers are no better off than the other classes of retailers. Wal-Mart may have become more powerful, but the power is far from widespread amongst other retailers.

The huge impact that Wal-Mart has on trends for general merchandisers leads us to revisit the industry level analysis, where we had initially found that retailers were better off than manufacturers in terms of MVA for as many as nine industries. Wal-Mart was included in the retailer group in eight of these nine industries. We redid the analysis after excluding Wal-Mart and found that only three industries remained where retailers were better off in terms of MVA-apparel, computers and jewelry. There were no significant changes in the trends observed for the other variables. It would seem that the evidence in support of an increase in the potential power of a single class of retailers is largely the consequence of just one firm's increasing power. Let us take a look at this firm.

\section{How is Wal-Mart doing?}

Figure 6 shows that Wal-Mart's Gross Margin/Sales and ROS over the past ten years have been declining, or at best remained steady. But, as we have argued earlier in this paper, these traditional profit measures do not provide a complete picture. Wal-Mart is a growth oriented firm that is intent on establishing a superior long-term cost position versus its competitors and has invested heavily towards that objective. That this investment has been wisely made is clear from the steep incline in the company's EVA and MVA over the same period, as depicted in Figures 7 and 8 . In contrast, close competitors like Kmart have barely managed to keep their EVA stable, while others like Sears have taken severe hits.

\section{Other Category Killers}

Toys R Us and Home Depot are two other giant retailers that have attracted a lot of attention over the past few years, although not quite as much as Wal-Mart. We examined these two companies as well. The last two columns of Table 6 summarize the results, none of which are surprising. The trends in each measure for these two companies follow WalMart's pattern, although they have not performed nearly as well as the latter. Toys R Us has been increasing its EVA at the rate of $\$ 6$ million per year, in contrast with Wal-Mart's \$84 million, while Home Depot has been holding it steady. Although both companies are improving their MVA at higher yearly rates (\$706 million and \$1416 million respectively) than the average retailer, they are far behind Wal-Mart's annual increase of $\$ 5725$ million. Thus, these category killers are significantly better than average, but they do not match the stellar performance, both present and potential, of Wal-Mart. 


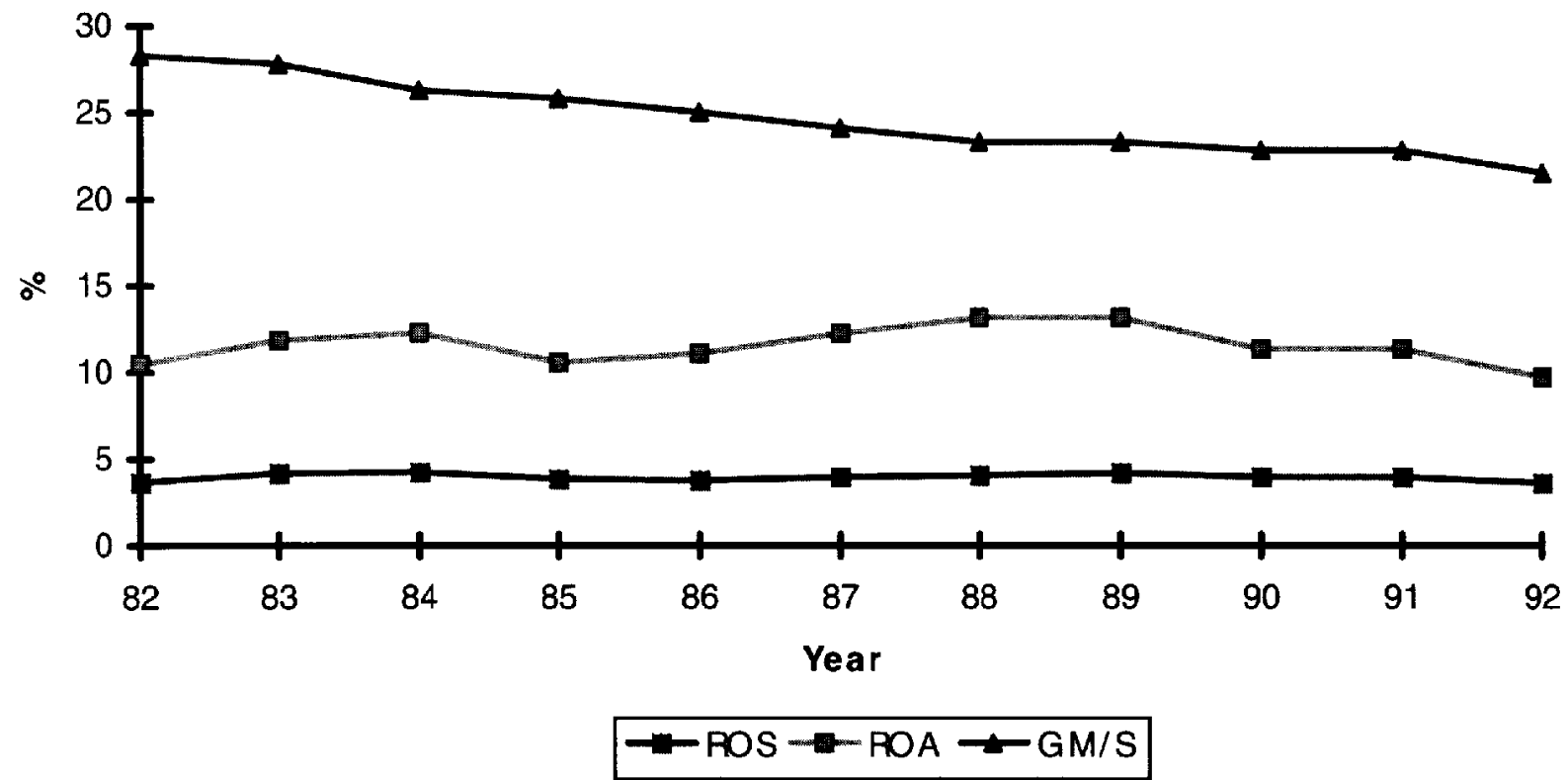

Figure 6. Wal-Mart's Rates of Return 


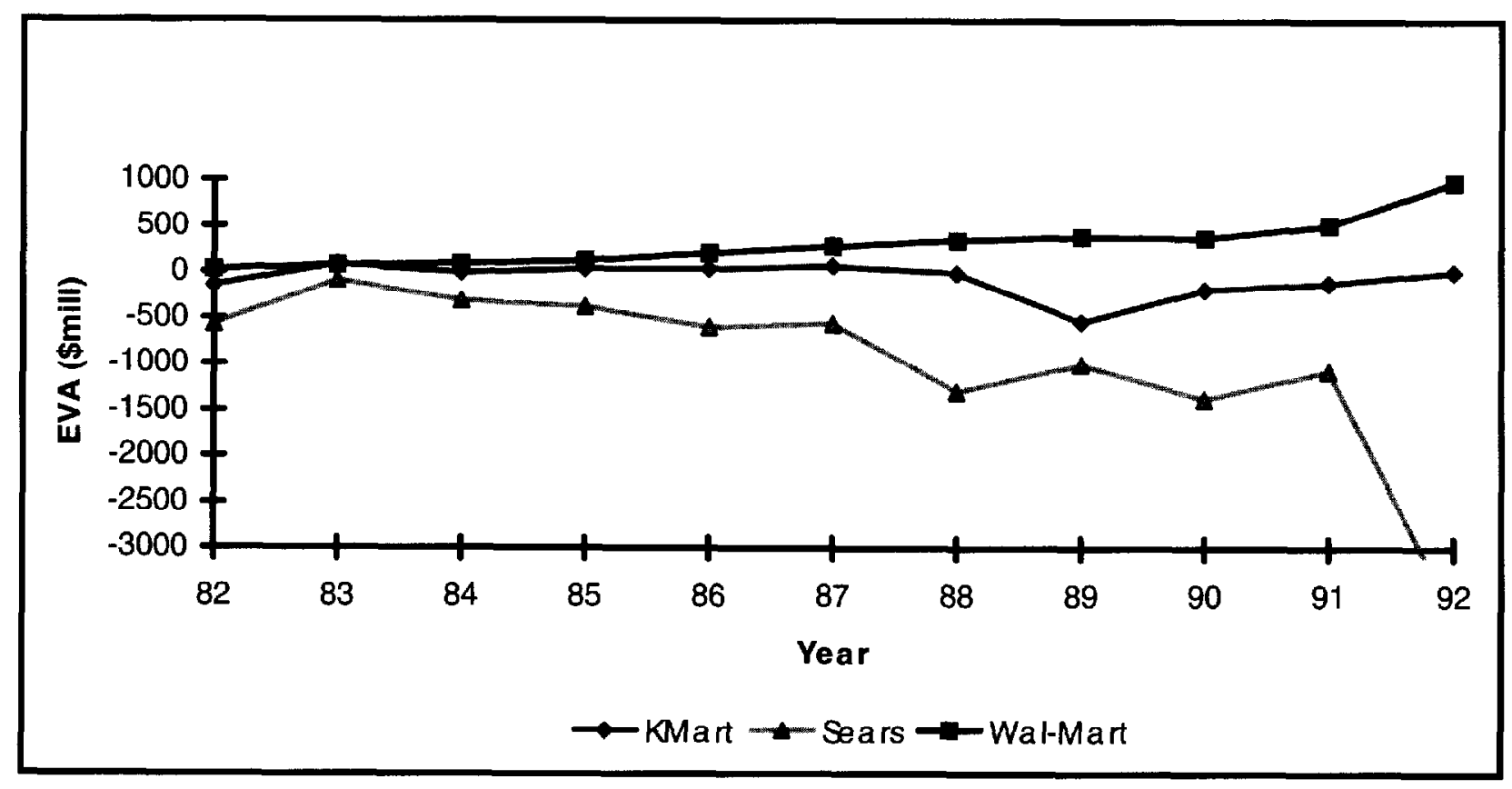

Figure 7. EVA for Wal-Mart, Kmart and Sears 


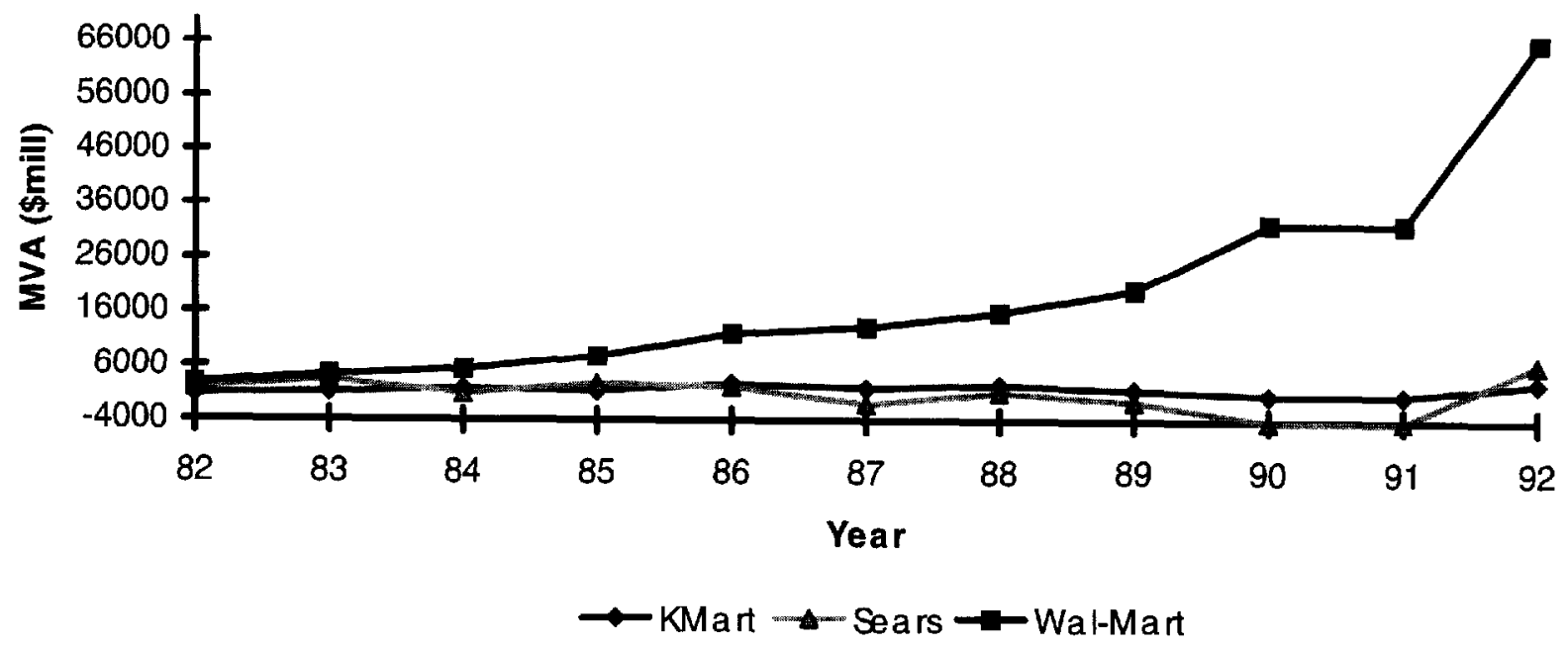

Figure 8. MVA for Wal-Mart, Kmart and Sears 


\section{CONCLUSION}

This paper has examined the purported shift in power from manufacturers to retailers using more complete measures of market power and a broader sample of industries and retail classes than used in the two recent empirical investigations of the issue. It may also be useful to investigate the role of wholesalers in the vertical channel system. There is little reference in the business or academic press to the power of wholesalers, perhaps because they have neither the "store equity" nor the "brand equity" to differentiate themselves. Still, an empirical analysis of their performance vis a vis manufacturers and retailers should be useful.

\section{Power Shift: Dyadic Versus Aggregate View}

Our analysis suggests that, over the past decade, retailers have been faring worse than manufacturers, with only a few exceptions. Our data do support, quite clearly, an increase in the power of the growing Wal-Mart. Just as clearly, however, they show that not all retailers have become more powerful, and many have lost power. We are witnessing an era of inter-retailer competition in which some retailers like Wal-Mart compete with others by lowering their Gross Margins. To keep this strategy viable, they focus on lowering operating costs and the cost of invested capital. The success of this handful of retailers is simply evidence of one (or some) retailers gaining power over other retailers, nol of manufacturers, in general, losing power with respect to retailers. Clearly, neither academics and practitioners have been making this important distinction (see Dickinson and Hollander, 1995 for a discussion of this issue). In specific given dyadic relationships, Wal-Mart and other low-cost discounters like Toys-R-Us may have become more powerful, but that certainly does not justify the sweeping statements that are being made so frequently, about a general increase in the market power of retailers. Having laid the issue of a general increase in retail power to rest, a fruitful direction for future research would be to study the dynamics of dyadic relationships of specific manufacturers and these few powerful retailers, and compare them with corresponding dyads that they form with the large majority of retailers. ${ }^{\text {? }}$

\section{Power Shifts Without Profit Shifts}

Is it possible for changes in relative power to not necessarily result in changes in relative profit? Increases in power need not lead to immediate gains in profit either because businesses may not know how to use their power (in which case the power shift is meaningless), or because (as we have discussed in this paper) they may use it in ways that preserve future independence rather than increase short term profit. That is why we examine not only current profit but potential for future profit as well. 
It may be argued that manufacturers have driven down their costs of operation to become more efficient than retailers and, consequently, their profit has increased despite a loss of market power. We believe such an argument misses a major point. Over the long term, and ten years is certainly long enough, any efficiencies that one channel member might gain will be bargained away by the other partner if the latter is more powerful. As noted by Porter (1990), "powerful buyers or suppliers bargain away the profits for themselves"(p. ). When General Motors was suffering large losses and its suppliers were not, the situation was not tolerated. Large discounts were demanded by GM and obtained. In exactly the same way as GM's power was wielded by the company's ex vice-president of worldwide purchasing, in bringing down prices of efficient automotive suppliers, retailers should be able to extract away profits from manufacturers, irrespective of the source of those profits. It is not reasonable to say that the trade has become more powerful relative to manufacturers if, over the long term, we continue to observe the opposite trend in their relative profit, both present and potential. Without either profit or market value, power is only a chimera, comprised of the trappings but not the substance.

It may also be argued that factors other than relative power affect profitability and, were it not for the power shift, those factors may well have made retailers even worse off than they are today. Unfortunately, this argument too is indefensible. The most common factors to be considered, according to Industrial Organization theory, are Concentration and Product Differentiation (measured, in this context, by variables such as Advertising expenditure and Private labeling). We have seen, in this paper, that there are few significant differences in Advertising trends for the two groups. Messinger and Narasimhan (1995) have documented increases in private labels in the grocery industry during the seventies and eighties. These authors also document some increases in grocery retailer concentration, especially at the regional level. ${ }^{8}$ Yet, retailer profitability has suffered. We are skeptical that the publicized growth in private labels is a signal of growing retail power. While some firms, like Wal-Mart, have increased private labeling, others, like Sears, have had to reduce emphasis on their own labels, and the net is not at all clear. And, retailer concentration, even if does increase, can lead to increased market power only if there is a concomitant decrease in competition.

\section{The Role of Inter-Retailer Competition}

Inter-retailer competition has only intensified over the past decade and this pressure forces them to compete away their profits. There is no doubt about that. What are the implications about the market power of retailers, though? We would point to the premise of the Structure-Conduct-Performance (SCP) paradigm - an industry can enjoy market power and abnormal profits (the "performance" in SCP) as it gets more concentrated (the "structure" link) only if firms in the industry are able to collude (the "conduct" link) and reduce competition (hence the well-known term "monopoly power"). In other words, reduced horizontal competition is a necessary pre-condition for increased market power and profitability. That critical link in the SCP paradigm has not been made by retailers. If it had, the result would be intense inter-manufacturer competition, which would force manufac- 
turers to compete their profits away to retailers. To summarize, increased retailer power should have led to: (1) high manufacturer competition and low manufacturer profits; and (2) low retailer competition and high retailer profits. What we observe in most industries is quite the opposite.

We conclude with the following quotes from the business press:

Private labels are like a creeping paralysis. Unless manufacturers, individually as well as in concert, take a militant attitude and attempt to stem this encroachment, the paralysis will proceed from the extremities and eventually strike at the heart, rendering the brand manufacturer innobile (p. )

Manufacturers are going to have to accept the rather unpleasant truth that with the tremendous power the chain wields, whether it he national, regional or local, it is the retailer who now has the supreme power to make or break a product in his own stores (p. ).

Amazing as it may seem, these proclamations were made more than three decades ago by Zimmerman (1959)! Clearly, the current furor is not the first time that private labels and retailers have been seen as a threat to national brands and the power of the manufacturers.

\section{APPENDIX}

\section{TABLE A-1}

\section{Sampled Industries with SIC Codes}

\begin{tabular}{l} 
Manufactures \\
\hline 1. Apparel \\
2300 Apparel and other finished products \\
2320 Men, boys fins, wrk clthg. \\
2330 Womens, misses, jrs. outerwear \\
2340 Womens, miss, chld, inft. undgrmt \\
2390 Misc. fabricated textile products
\end{tabular}

\section{Appliances}

3600 Electric, other elec. eq. ex cmp. 3630 Household appliances 3634 Electric Housewares and fans

\section{Audio And Video Equipment}

3651 Household audio and video eq. 3652 Phonog. records, audio tape, disk

\section{Computers}

3570 Computer and office equipment 3571 Electronic computers 3572 Computer Storage devices 3575 Computer Terminals 3576 Computer communication equip. 3577 Computer peripheral eq. nec

\section{Retailers}

5600 Apparel and accessory stores

5621 Women's clothing

5651 Family clothing

5311 Department Stores

5331 Variety stores

5399 Misc. Ceneral Mdse. stores

5731 Radio, tv, cons. elect. stores

$$
531153315399^{\#}
$$

5731 Radio, tv consumer elert. 5735 Record and tape

$$
\begin{array}{lll} 
& + \\
5311 & 5331 & 5399^{\#}
\end{array}
$$

5734 Computer and Computer Software

$$
531153315399^{*}
$$


TABLE A-1

\section{Continued}

5. Drugs Manufactures

2834 Pharmaceutical preparations

\section{Food and Beverages} 2000 Food and Kindred Products 2011, 2013,2015 ---.- 2099

\section{Footwear}

3021 Rubber and plastics footwear 3140 Footwear, except rubber

\section{Furniture}

2510 Household furniture

2511 Wood hshld furn., except. upholstered

2520 Office furniture

2522 Office furniture ex. wood

2531 Public bidg. \& rel. furniture

2540 Partitions, shelving, lockers

2590 Misc. furniture and fixtures

9. Jewelry and Watches

3873 Watches, clocks and parts

3910 Jewelry, silverware, plated ware

3911 Jeweiry and Precious Metals

10. Office Machines

3578 Calculate, acct. mach exc. computer 3579 Office machines

11. Tobacco Products

2100 Tobacco products

2111 Cigarettes

\section{Toiletries and Cleaning Aids}

2840 Soap, detergent, toilet preps 2842 Special clean, polish preps 2844 Perfume, cosmetic, luilet prep.

\section{Toys and Games}

3942 Dolls, stuffed toys

3944 Games, toys, child veh, except dolls

\section{Wood and Lumber Products}

2400 Lumber and wood products, except furn.

2421 Sawmills, planing mills, gen. 2430 Millwork, veneer, plywood
5912 Drug and Proprietary

5400 Food stores

5411 Grocery Stores

5412 Convenience stores

5400 Food Stores

5411 Grocery Stores

5412 Convenience Stores

5661 Shoe stores

$$
\begin{array}{lll} 
& + & \\
5311 & 5331 & 5399^{\#}
\end{array}
$$

5700 Home furniture and equip.

5712 Furniture

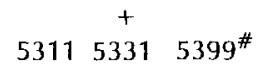

5944 Jewelry

$$
\begin{array}{ccc} 
& + & \\
5311 & 5331 & 5399^{\#} \\
5311 & 5331 & 5399^{\#}
\end{array}
$$

5912 Drug and Proprietary Stores

$$
\begin{array}{ccc} 
& + & \\
5400 & 5411 & 5412^{@}
\end{array}
$$

5411 Grocery stores

5412 Convenience stores

5912 Drug \& proprietary stores

$$
\begin{array}{ccc} 
& + \\
5311 & 5331 & 5399^{\#}
\end{array}
$$

5945 Hobby, toy and game shops

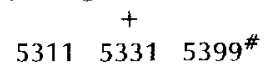

5200 Building material hardware, garden 5211 Lumber and other build. material

Notes: \# These three SICs are defined under Apparel Retailers

(a) These SICs are defined under Drug Retailers 
TABLE A-2

Trend Regression Coefficients for all Industries

\begin{tabular}{|c|c|c|c|c|c|c|c|c|c|c|}
\hline \multirow[b]{2}{*}{ Channel Member } & \multicolumn{10}{|c|}{ Performance Measure } \\
\hline & GM/S & ROS & ROA & ROI & $E V A$ & $E V A / S$ & MVA & $1 / S$ & SC\&A/S & $A \& P / S$ \\
\hline Apparel Manufacturers & $0.45 *$ & $0.24^{*}$ & $0.34^{*}$ & $0.58^{*}$ & $1.51^{*}$ & $0.44^{*}$ & $11.03 *$ & -0.02 & $0.14^{*}$ & $0.08 *$ \\
\hline Apparel Specialty Retailers & $\begin{array}{c}(0.09) \\
0.14\end{array}$ & $\begin{array}{l}(0.10) \\
-0.05\end{array}$ & $\begin{array}{c}(0.14) \\
-0.27^{*}\end{array}$ & $\begin{array}{r}(0.21) \\
-0.38^{*}\end{array}$ & $\begin{array}{l}(0.34) \\
-0.13\end{array}$ & $\begin{array}{l}(0.10) \\
0.02\end{array}$ & $\begin{array}{c}(2.80) \\
43.34^{*}\end{array}$ & $\begin{array}{c}(0.14) \\
-0.18^{*}\end{array}$ & $\begin{array}{c}(0.04) \\
0.18^{*}\end{array}$ & $\begin{array}{c}(0.03) \\
-0.02\end{array}$ \\
\hline Apparel Retailers & $\begin{array}{c}(0.10) \\
-0.29 * \\
(0.05)\end{array}$ & $\begin{array}{c}(0.03) \\
-0.14^{*} \\
(0.03)\end{array}$ & $\begin{array}{c}(0.06) \\
-0.20^{*} \\
(0.04)\end{array}$ & $\begin{array}{c}(0.09) \\
-0.34^{*} \\
(0.09)\end{array}$ & $\begin{array}{c}(0.22) \\
-0.97 \\
(1.03)\end{array}$ & $\begin{array}{c}(0.04) \\
0.00 \\
(0.04)\end{array}$ & $\begin{array}{c}(11.27) \\
103.10^{*} \\
(14.73)\end{array}$ & $\begin{array}{c}(0.05) \\
-0.15 \\
(0.09)\end{array}$ & $\begin{array}{c}(0.07) \\
-0.11 * \\
(0.05)\end{array}$ & $\begin{array}{c}(0.02) \\
-0.07^{*} \\
(0.01)\end{array}$ \\
\hline Appliance Manufacturers & 0.12 & $-0.15^{*}$ & $-0.49 *$ & $-0.66^{*}$ & 2.62 & 0.04 & $153.85 * *$ & & $-0.23^{* *}$ & $-0.06 * *$ \\
\hline Appliance Specialty Retailers & $\begin{array}{c}(0.15) \\
-2.79^{*}\end{array}$ & $\begin{array}{c}(0.06) \\
-0.77^{*}\end{array}$ & $\begin{array}{c}(0.06) \\
-1.28^{*}\end{array}$ & $\begin{array}{l}(0.12) \\
-1.39 *\end{array}$ & $\begin{array}{c}(6.11) \\
-2.56^{*}\end{array}$ & $\begin{array}{l}(0.06) \\
-0.35 *\end{array}$ & $\begin{array}{l}(68.77) \\
-79.61^{*}\end{array}$ & $\begin{array}{c}(0.09) \\
-0.96^{*}\end{array}$ & $\begin{array}{c}(0.10) \\
-1.46^{*}\end{array}$ & $\begin{array}{c}(0.03) \\
-0.42 *\end{array}$ \\
\hline Appliance Retailers & $\begin{array}{c}(0.37) \\
-0.41^{*} \\
(0.05)\end{array}$ & $\begin{array}{c}(0.10) \\
-0.16^{*} \\
(0.04)\end{array}$ & $\begin{array}{c}(0.19) \\
-0.23^{*} \\
(0.04)\end{array}$ & $\begin{array}{c}(0.23) \\
-0.38^{*} \\
(0.10)\end{array}$ & $\begin{array}{c}(0.40) \\
-1.60 \\
(1.51)\end{array}$ & $\begin{array}{c}(0.05) \\
-0.01 \\
(0.05)\end{array}$ & $\begin{array}{c}(24.51) \\
113.11^{*} \\
(18.15)\end{array}$ & $\begin{array}{c}(0.17) \\
-0.14 \\
(0.10)\end{array}$ & $\begin{array}{c}(0.27) \\
-0.19^{*} \\
(0.05)\end{array}$ & $\begin{array}{c}(0.05) \\
-0.08^{*} \\
(0.02)\end{array}$ \\
\hline Audio-Video Spccialty Retailers & $\begin{array}{c}0.36 \\
(0.26) \\
-2.51 *\end{array}$ & $\begin{array}{c}-0.03 \\
(0.09) \\
-0.75^{*}\end{array}$ & $\begin{array}{c}-0.11 \\
(0.10) \\
-1.29 *\end{array}$ & $\begin{array}{c}-0.21 \\
(0.19) \\
-1.46^{*}\end{array}$ & $\begin{array}{c}-0.05 \\
(1.10) \\
-1.54^{*}\end{array}$ & $\begin{array}{c}0.25^{*} \\
(0.07) \\
-0.33^{*}\end{array}$ & $\begin{array}{c}45.31 * * \\
(24.29) \\
-60.32 *\end{array}$ & $\begin{array}{c}-0.76^{*} \\
(0.15) \\
-0.89^{*}\end{array}$ & $\begin{array}{c}0.22^{* *} \\
(0.12) \\
-1.30^{*}\end{array}$ & $\begin{array}{c}-0.16 \\
(0.13) \\
-0.43 *\end{array}$ \\
\hline Audio/Nideo Retailers & $\begin{array}{c}(0.35) \\
-0.39 * \\
(0.05)\end{array}$ & $\begin{array}{c}(0.09) \\
-0.16^{*} \\
(0.04)\end{array}$ & $\begin{array}{c}(0.17) \\
-0.23^{*} \\
(0.04)\end{array}$ & $\begin{array}{c}(0.20) \\
-0.38^{*} \\
(0.10)\end{array}$ & $\begin{array}{c}(0.27) \\
-1.43 \\
(1.40)\end{array}$ & $\begin{array}{c}(0.05) \\
-0.01 \\
(0.05)\end{array}$ & $\begin{array}{c}(17.96) \\
105.41 * \\
(17.59)\end{array}$ & $\begin{array}{c}(0.17) \\
-0.13 \\
(0.10)\end{array}$ & $\begin{array}{c}(0.25) \\
-0.18^{*} \\
(0.05)\end{array}$ & $\begin{array}{c}(0.05) \\
-0.08^{*} \\
(0.02)\end{array}$ \\
\hline $\begin{array}{l}\text { Computer Manufacturers } \\
\text { Computer Specialty Retailers }\end{array}$ & $\begin{array}{c}-0.34 \\
(0.20) \\
-5.83^{*}\end{array}$ & $\begin{array}{c}-0.95^{*} \\
(0.18) \\
-0.44\end{array}$ & $\begin{array}{c}-0.95 * \\
(0.17) \\
-0.39\end{array}$ & $\begin{array}{c}-1.61^{*} \\
(0.32) \\
0.23\end{array}$ & $\begin{array}{c}-8.06 * \\
(1.45) \\
0.46\end{array}$ & $\begin{array}{l}-0.57^{*} \\
(0.15) \\
0.62 * *\end{array}$ & $\begin{array}{c}-86.48^{*} \\
(12.21) \\
33.68^{* *}\end{array}$ & $\begin{array}{l}-0.19 \\
(0.14) \\
-1.24\end{array}$ & $\begin{array}{c}0.55^{*} \\
(0.09) \\
-4.88^{*}\end{array}$ & $\begin{array}{c}-0.01 \\
(0.02) \\
0.32^{*}\end{array}$ \\
\hline Computer Retailers & $\begin{array}{c}(1.67) \\
-0.39 * \\
(0.06)\end{array}$ & $\begin{array}{c}(0.34) \\
-0.15^{*} \\
(0.04)\end{array}$ & $\begin{array}{c}(0.80) \\
-0.22^{*} \\
(0.04)\end{array}$ & $\begin{array}{c}(1.23) \\
-0.36^{*} \\
(0.10)\end{array}$ & $\begin{array}{l}(0.35) \\
-1.65 \\
(1.66)\end{array}$ & $\begin{array}{c}(0.28) \\
-0.01 \\
(0.05)\end{array}$ & $\begin{array}{l}(13.08) \\
144.49^{*} \\
(19.25)\end{array}$ & $\begin{array}{l}(0.74) \\
-0.15 \\
(0.10)\end{array}$ & $\begin{array}{c}(1.34) \\
-0.19 * \\
(0.05)\end{array}$ & $\begin{array}{c}(0.00) \\
-0.08^{*} \\
(0.02)\end{array}$ \\
\hline Drug Manufacturer s & $\begin{array}{c}1.51 * \\
(0.07) \\
0.24^{*} \\
(0.03)\end{array}$ & $\begin{array}{c}0.58^{*} \\
(0.04) \\
-0.13 * \\
(0.03)\end{array}$ & $\begin{array}{c}0.39^{*} \\
(0.06) \\
-0.59^{*} \\
(0.11)\end{array}$ & $\begin{array}{c}0.93 * \\
(0.10) \\
-0.95 * \\
(0.18)\end{array}$ & $\begin{array}{c}12.09 * \\
(1.18) \\
-0.10 \\
(0.61)\end{array}$ & $\begin{array}{c}0.82 * \\
(0.07) \\
-0.00 \\
(0.02)\end{array}$ & $\begin{array}{c}359.30 * \\
(48.81) \\
46.75 * \\
(10.04)\end{array}$ & $\begin{array}{c}-0.52 * \\
(0.04) \\
0.02 \\
(0.03)\end{array}$ & $\begin{array}{c}0.76^{*} \\
(0.06) \\
0.14^{*} \\
(0.04)\end{array}$ & $\begin{array}{c}-0.13^{*} \\
(0.04) \\
-0.03^{*} \\
(0.01)\end{array}$ \\
\hline Footwear Specialty Retailers & $\begin{array}{c}0.40^{*} \\
(0.11) \\
0.49^{*}\end{array}$ & $\begin{array}{c}0.18 \\
(0.14) \\
0.39\end{array}$ & $\begin{array}{c}0.32 \\
(0.25) \\
0.67\end{array}$ & $\begin{array}{c}0.36 \\
(0.33) \\
1.01\end{array}$ & $\begin{array}{c}1.07^{*} \\
(0.38) \\
0.86\end{array}$ & $\begin{array}{c}0.30^{*} \\
(0.12) \\
0.10\end{array}$ & $\begin{array}{c}22.14^{*} \\
(5.16) \\
0.63\end{array}$ & $\begin{array}{c}-0.43^{*} \\
(0.10) \\
1.24^{*}\end{array}$ & $\begin{array}{c}0.19 * * \\
(0.10) \\
0.25 * *\end{array}$ & $\begin{array}{c}0.15 * \\
(0.05) \\
-0.01\end{array}$ \\
\hline Footwear Retailers & $\begin{array}{c}(0.13) \\
-0.38^{*} \\
(0.06)\end{array}$ & $\begin{array}{c}(0.25) \\
-0.15 * \\
(0.04)\end{array}$ & $\begin{array}{c}(0.48) \\
-0.21 * \\
(0.05)\end{array}$ & $\begin{array}{c}(0.69) \\
-0.36^{*} \\
(0.10)\end{array}$ & $\begin{array}{c}(1.18) \\
-1.76 \\
(1.64)\end{array}$ & $\begin{array}{c}(0.23) \\
-0.01 \\
(0.05)\end{array}$ & $\begin{array}{c}(4.32) \\
143.61 * \\
(19.23)\end{array}$ & $\begin{array}{c}(0.19) \\
-0.14 \\
(0.10)\end{array}$ & $\begin{array}{c}(0.14) \\
-0.19 * \\
(0.06)\end{array}$ & $\begin{array}{c}(0.02) \\
-0.08^{*} \\
(0.02)\end{array}$ \\
\hline
\end{tabular}


TABLE A-2

Trend Regression Coefficients for all Industries

\begin{tabular}{|c|c|c|c|c|c|c|c|c|c|c|}
\hline \multirow[b]{2}{*}{ Channel Member } & \multirow[b]{2}{*}{$G M / S$} & \multicolumn{8}{|c|}{ Performance Measure } & \multirow[b]{2}{*}{$A \& P / S$} \\
\hline & & ROS & $R O A$ & $R O I$ & EVA & EVA/S & $M V A$ & $1 / 5$ & $S C \& A / S$ & \\
\hline Furniture Manufacturers & $-0.35^{*}$ & $-0.27 * *$ & $-0.48^{*}$ & $-0.53^{*}$ & 0.03 & 0.11 & $12.89^{*}$ & $-0.73^{*}$ & $-0.23^{*}$ & $0.04^{*}$ \\
\hline Furniture Specialty Retailers & $\begin{array}{c}(0.14) \\
-0.52 *\end{array}$ & $\begin{array}{l}(0.14) \\
-0.36\end{array}$ & $\begin{array}{c}(0.17) \\
-0.50\end{array}$ & $\begin{array}{l}(0.22) \\
-0.72\end{array}$ & $\begin{array}{c}(0.45) \\
-0.12\end{array}$ & $\begin{array}{c}(0.14) \\
0.05\end{array}$ & $\begin{array}{c}(0.01) \\
5.62\end{array}$ & $\begin{array}{c}(0.11) \\
-0.01\end{array}$ & $\begin{array}{c}(0.11) \\
-0.21\end{array}$ & $\begin{array}{c}(0.02) \\
-0.10\end{array}$ \\
\hline Furniture Retailers & $\begin{array}{c}(0.21) \\
-0.38 * \\
(0.06)\end{array}$ & $\begin{array}{c}(0.21) \\
-0.16^{*} \\
(0.04)\end{array}$ & $\begin{array}{c}(0.29) \\
-0.22^{*} \\
(0.05)\end{array}$ & $\begin{array}{c}(0.45) \\
-0.37^{*} \\
(0.10)\end{array}$ & $\begin{array}{l}(0.42) \\
-1.45 \\
(1.40)\end{array}$ & $\begin{array}{c}(0.21) \\
-0.01 \\
(0.05)\end{array}$ & $\begin{array}{c}(3.15) \\
120.06^{*} \\
(16.91)\end{array}$ & $\begin{array}{c}(0.05) \\
-0.14 \\
(0.10)\end{array}$ & $\begin{array}{c}(0.14) \\
-0.18^{*} \\
(0.05)\end{array}$ & $\begin{array}{c}(0.08) \\
-0.07 * \\
(0.02)\end{array}$ \\
\hline $\begin{array}{l}\text { Jewelry Manufacturers } \\
\text { Jewelry Specialty Retailers }\end{array}$ & $\begin{array}{c}-0.31 * \\
(0.09) \\
-2.01 *\end{array}$ & $\begin{array}{l}-0.14 \\
(0.14) \\
-0.26\end{array}$ & $\begin{array}{l}-0.25 \\
(0.19) \\
-0.31\end{array}$ & $\begin{array}{l}-0.36 \\
(0.30) \\
-0.88\end{array}$ & $\begin{array}{c}-0.20 \\
(0.22) \\
3.75\end{array}$ & $\begin{array}{c}0.04 \\
(0.15) \\
0.22\end{array}$ & $\begin{array}{l}7.96 * \\
(1.50) \\
20.11 *\end{array}$ & $\begin{array}{c}0.26 \\
(0.19) \\
0.87^{*}\end{array}$ & $\begin{array}{l}-0.33^{* *} \\
(0.15) \\
-2.17^{*}\end{array}$ & $\begin{array}{c}0.02 \\
(0.02) \\
-0.30^{*}\end{array}$ \\
\hline Jewelry Retailers & $\begin{array}{c}(0.45) \\
-0.39 * \\
(0.06)\end{array}$ & $\begin{array}{c}(0.39) \\
-0.15^{*} \\
(0.04)\end{array}$ & $\begin{array}{c}(0.41) \\
-0.22^{*} \\
(0.05)\end{array}$ & $\begin{array}{c}(0.85) \\
-0.37^{*} \\
(0.10)\end{array}$ & $\begin{array}{c}(2.27) \\
-1.48 \\
(1.61)\end{array}$ & $\begin{array}{c}(0.40) \\
-0.00 \\
(0.05)\end{array}$ & $\begin{array}{c}(7.43) \\
130.52^{*} \\
(17.23)\end{array}$ & $\begin{array}{c}(0.27) \\
-0.13 \\
(0.10)\end{array}$ & $\begin{array}{c}(0.37) \\
-0.20^{*} \\
(0.06)\end{array}$ & $\begin{array}{c}(0.09) \\
-0.08^{*} \\
(0.02)\end{array}$ \\
\hline $\begin{array}{l}\text { Off. Mach Manufacturer s } \\
\text { Off. Mach Retailers }\end{array}$ & $\begin{array}{c}0.76^{*} \\
(0.10) \\
-0.38^{*} \\
(0.06)\end{array}$ & $\begin{array}{c}-0.05 \\
(0.08) \\
-0.15^{*} \\
(0.04)\end{array}$ & $\begin{array}{c}-0.45^{*} \\
(0.11) \\
-0.22^{*} \\
(0.04)\end{array}$ & $\begin{array}{c}-0.61^{*} \\
(0.20) \\
-0.37^{*} \\
(0.10)\end{array}$ & $\begin{array}{c}-0.03 \\
(0.38) \\
-1.93 \\
(1.68)\end{array}$ & $\begin{array}{c}-0.02 \\
(0.13) \\
-0.01 \\
(0.05)\end{array}$ & $\begin{array}{c}18.91 * \\
(5.08) \\
151.50^{*} \\
(19.96)\end{array}$ & $\begin{array}{c}-0.33^{*} \\
(0.12) \\
-0.15 \\
(0.10)\end{array}$ & $\begin{array}{c}-0.10 \\
(0.06) \\
-0.19 * \\
(0.06)\end{array}$ & $\begin{array}{c}-0.07^{*} \\
(0.03) \\
-0.08^{*} \\
(0.02)\end{array}$ \\
\hline $\begin{array}{l}\text { Tobacco Manufacturers } \\
\text { Tobacco Retailers }\end{array}$ & $\begin{array}{c}2.11^{*} \\
(0.22) \\
0.24^{*} \\
(0.03)\end{array}$ & $\begin{array}{c}0.13 \\
(0.16) \\
-0.13^{*} \\
(0.03)\end{array}$ & $\begin{array}{c}-0.36^{* *} \\
(0.18) \\
-0.59^{*} \\
(0.11)\end{array}$ & $\begin{array}{c}-0.35 \\
(0.34) \\
-0.95^{*} \\
(0.18)\end{array}$ & $\begin{array}{c}34.10 * \\
(10.01) \\
-0.10 \\
(0.61)\end{array}$ & $\begin{array}{c}0.44 * \\
(0.17) \\
-0.00 \\
(0.02)\end{array}$ & $\begin{array}{c}360.50^{*} \\
(125.37) \\
46.75^{*} \\
(10.04\end{array}$ & $\begin{array}{c}-0.92 * \\
(0.14) \\
0.02 \\
(0.03)\end{array}$ & $\begin{array}{c}0.90^{*} \\
(0.07) \\
0.14 * \\
(0.04)\end{array}$ & $\begin{array}{c}-0.10^{*} \\
(0.05) \\
-0.03^{*} \\
(0.01)\end{array}$ \\
\hline $\begin{array}{l}\text { Toiletries Manufacturers } \\
\text { Toiletries Retailers }\end{array}$ & $\begin{array}{c}0.73^{*} \\
(0.13) \\
-0.12^{*} \\
(0.04)\end{array}$ & $\begin{array}{c}0.02 \\
(0.07) \\
-0.14^{*} \\
(0.03)\end{array}$ & $\begin{array}{c}-0.12 \\
(0.13) \\
-0.29 * \\
(0.05)\end{array}$ & $\begin{array}{c}-0.00 \\
(0.21) \\
-0.51 * \\
(0.09)\end{array}$ & $\begin{array}{c}3.98^{*} \\
(0.72) \\
-0.92 \\
(0.98)\end{array}$ & $\begin{array}{c}0.32 * \\
(0.06) \\
-0.01 \\
(0.03)\end{array}$ & $\begin{array}{c}81.10^{*} \\
(9.39) \\
99.91^{*} \\
(11.00)\end{array}$ & $\begin{array}{c}-0.15 * \\
(0.06) \\
-0.05 \\
(0.06)\end{array}$ & $\begin{array}{c}0.61^{*} \\
(0.13) \\
-0.06^{* *} \\
(0.04)\end{array}$ & $\begin{array}{c}0.22 * \\
(0.03) \\
-0.05 * \\
(0.01)\end{array}$ \\
\hline $\begin{array}{l}\text { Toy Manufacturers } \\
\text { Toy Specialty Retailers }\end{array}$ & $\begin{array}{c}0.24 \\
(0.20) \\
-0.21^{*}\end{array}$ & $\begin{array}{c}-0.11 \\
(0.27) \\
0.20\end{array}$ & $\begin{array}{c}-0.34 \\
(0.37) \\
0.21\end{array}$ & $\begin{array}{c}-0.63 \\
(0.56) \\
0.12\end{array}$ & $\begin{array}{c}-0.39 \\
(0.89) \\
2.83 *\end{array}$ & $\begin{array}{c}-0.19 \\
(0.27) \\
0.25^{* *}\end{array}$ & $\begin{array}{c}26.33^{*} \\
(8.00) \\
153.32^{*}\end{array}$ & $\begin{array}{c}-0.40^{* *} \\
(0.20) \\
0.27\end{array}$ & $\begin{array}{c}0.40^{*} \\
(0.16) \\
-0.25 *\end{array}$ & $\begin{array}{c}0.01 \\
(0.24) \\
-0.19 *\end{array}$ \\
\hline Toy Retailers & $\begin{array}{c}(0.05) \\
-0.37^{*} \\
(0.06)\end{array}$ & $\begin{array}{c}(0.12) \\
-0.14 * \\
(0.04)\end{array}$ & $\begin{array}{c}(0.19) \\
-0.20 * \\
(0.05)\end{array}$ & $\begin{array}{c}(0.33) \\
-0.34^{*} \\
(0.10)\end{array}$ & $\begin{array}{c}(0.70) \\
-1.67 \\
(1.61)\end{array}$ & $\begin{array}{c}(0.12) \\
-0.00 \\
(0.05)\end{array}$ & $\begin{array}{c}(15.68) \\
151.81 * \\
(19.06)\end{array}$ & $\begin{array}{c}(0.19) \\
-0.13 \\
(0.10)\end{array}$ & $\begin{array}{c}(0.04) \\
-0.18 * \\
(0.05)\end{array}$ & $\begin{array}{c}(0.03) \\
-0.09 * \\
(0.02)\end{array}$ \\
\hline Wood Manufacturers & $\begin{array}{c}0.56^{*} \\
(0.20) \\
-0.11 * \\
(0.04)\end{array}$ & $\begin{array}{c}0.02 \\
(0.24) \\
-0.25 * \\
(0.05)\end{array}$ & $\begin{array}{c}0.00 \\
(0.29) \\
-0.51 * \\
(0.10)\end{array}$ & $\begin{array}{c}0.01 \\
(0.39) \\
-0.65 * \\
(0.13)\end{array}$ & $\begin{array}{c}2.14 \\
(2.23) \\
-0.57 * * \\
(0.31)\end{array}$ & $\begin{array}{c}0.36 \\
(0.26) \\
0.06 \\
(0.05) \\
\end{array}$ & $\begin{array}{c}16.35 \\
(9.61) \\
86.84^{*} \\
(27.47)\end{array}$ & $\begin{array}{c}-0.14 * * \\
(0.06) \\
-0.24 * \\
(0.04)\end{array}$ & $\begin{array}{c}0.18^{* *} \\
(0.08) \\
0.10 \\
(0.08)\end{array}$ & $\begin{array}{c}0.01 * \\
(0.00) \\
-0.16 * \\
(0.02)\end{array}$ \\
\hline
\end{tabular}

Notes: ${ }_{*}$ tandard Errors are in parentheses

Significant at $p=0.05 ;{ }^{* *}$ Significant at $p=0.10$ 
Acknowledgment: Thanks are due to Eric Olsen of the University of Virginia and Sonali Krishna of Dartmouth College for their assistance with data preparation. The first author gratefully acknowledges the support of the Tuck Associates Program, and thanks Clyde Stickney and Virginia Soybel for their helpful comments.

\section{NOTES}

1. The CSR simply means that book value at the end of a period is equal to the book value at the beginning of the period plus earnings minus dividends. Capital additions are incorporated as negative dividends (Fairfield 1994).

2. Future EVA need only be summed over a finite time horizon, because, ultimately, competitive pressures will bring the residual earnings of a firm down so that it no longer earns more than the cost of its capital (Fairfield 1994; Stickney 1995).

3. Of course, manufacturers, in turn, may be able to transfer some of their inventory costs to their own suppliers. Lack of data prevented us from separately analyzing raw matcrial, work-inprogress and finished goods inventory costs to disentangle these mechanisms.

4. Some currently used measures of EVA only take into account the cost of long term debt. We believe that short term debt is very important, especially for retailers, and its cost should also be taken into consideration.

5. See Rappaport (1986) for a simple explanation of the Capital Asset Pricing Model and Grabowski and Vernon (1990) for a recent illustration of the cost of capital calculation.

6. We recognize that all manufacturer firm-retailer firm dyads within an industry group may not have experienced the same, if any, power shift towards the retailer. However, as discussed earlier, our focus is on determining whether, on the whole, retailers in different industries are becoming more powerful than manufacturers.

7. On the subject of future research, it may also be useful to investigate the role of wholesalers in the vertical channel system. There is little reference in the business or academic press to the power of wholesalers, perhaps because they have neither the "store equity" nor the "brand equity" to differentiate themselves. Still, an empirical analysis of their performance vis a vis manufacturers and retailers will be worthwhile.

8. Our own preliminary analysis, using Census data from the U.S. Department of Commerce and COMPUSTAT, shows that over the period that we analyze, the percentage of total retail sales accounted for by the five largest retailers has increased slightly, from $8.3 \%$ to $10.1 \%$.

\section{REFERENCES}

Achenbaum, Alvin A. and F. Kent Mitchel. (1987). "Pulling Away From Push Marketing," Harvard Business Review, 65(May-June): 38-40.

Albion, Mark S. and Paul W. Farris. (1981). The Advertising Controversy: Evidence on the Economic Effects of Advertising. Auburn, MA: Auburn House.

Alderson, Wroe. (1955). Marketing Behavior and Executive Action: A Functionalist Approach to Marketing Theory. Homewood, IL: Richard D. Irwin.

Alpert, Frank H., Michael A. Kamins and John L. Graham. (1992). "An Examination of Reseller Buyer Attitudes Toward Order of Brand Entry," Journal of Marketing, 56: 25-37.

Bain, Joe S. (1968). Industrial Organization, 2nd ed. New York: John Wiley. 
Bates, Albert D. (1989). "The Extended Specialty Store: A Strategic Opportunity for the 1990s," Journal of Retailing, 65(3): 379-388.

Benston, George J. (1985). "The Validity of Profits-Structure with Particular Referenceto the FTC's Line of Business Data," American Economic Review, 75(March): 37-67.

Boulding, William, and Richard Staelin. (1990). "Environment, Market Share, and Market Power," Management Science, 36(10): 1160-1177.

Boyle, Brett, F. Robert Dwyer, Robert A. Robicheaux and James T. Simpson. (1992). "Influence Strategies in Marketing Channels: Measures and Use in Different Relationship Structures," Journal of Marketing Research, XXIX: 462-473.

Buzzell, Robert D., John A. Quelch and Walter J. Salmon. (1990). "The Costly Bargain of Trade Promotion," Harvard Business Review, (March-April): 141-149.

Chu, Wujin. (1992). "Demand Signalling and Screening in Channels of Distribution," Marketing Science, 11(4): 327-347.

Dickinson, Roger and Stanley Hollander. (1995). Some Definition Problems in Marketing Channels. Working paper, University of Texas at Arlington.

Dickson, Peter, Wendy Schneier, Carl Steidtmann and Paul Farris. (1994). The Competitive Dynamics of Global Sourcing. Working paper, Ohio State University.

El-Ansary, Adel I. and Louis W. Stern. (1972). "Power Measurement in the Distribution Channel," Journal of Marketing Research, IX(February): 47-52.

Emerson, Richard. (1962). "Power-Dependence Relations," American Sociological Review, 27: 31-41.

Fairfield, Patricia M. (1994), "P/E, P/B and the Present Value of Future Dividends," Financial Analysts Journal, (July-August): 23-31.

Farris, Paul W. and Kusum L. Ailawadi. (1992). "Retail Power: Monster or Mouse?," Journal of Retailing, 68(4): 351-369.

Feltham, Gerald A. and James A. Ohlson. (1994). "Valuation and Clean Surplus Accounting for Operating and Financial Activities," Contemporary Accounting Research, forthcoming.

Fisher, Franklin and John McGowan. (1983). "On the Misuse of Accounting Rates of Return to Infer Monopoly Profits," American Economic Review, 73(March): 82-97.

Frazier, Gary L. (1983). "On the Measurement of Interfirm Power in Channels of Distribution," Journal of Marketing Research, XX: 158-166.

Frazier, Gary L., and john O. Summers. (1984). "Interfirm Influence Strategies and Their Application Within Distribution Channels," Journal of Marketing, 48(Summer): 43-55.

French, John R., and Bertram Raven. (1959). "The Bases of Social Power." In Studies in Social Power, Dorwin Cartwright, ed. Ann Arbor: University of Michigan Press.

Fulop, Christina. (1988). "The Role of Advertising in the Retail Marketing Mix," International Journal of Advertising, 7: 99-117.

Gaski, John. (1988). "Distribution Channels: A Validation Study," International Journal of Physical Distribution \& Materials Management, 18(5): 16-33.

Gaski, John F., and John R. Nevin. (1957). "The Differential Effects of Exercised and Unexercised Power Sources in a Marketing Channel," Journal of Marketing Research, XXII (May): 130-142.

Gitman, Lawrence J. and Vincent A. Mercurio. (1982). "Cost of Capital Techniques Used by Major U.S. Firms," Financial Management, 11(4): 21-29.

Grabowski, Henry and Dennis Mueller. (1978). "Industrial Research and Development, Intangible Capital Stocks, and Firm Profit Rates," Bell Journal of Economics, 9(Autumn): 36-40.

Grabowski, Henry and John Vernon. (1990). "A New Lonk at the Returns and Risks in Pharmaceutical R\&D," Management Science, 36(7): 804-821.

Grant, Robert M. (1987). "Manufacturer-Retailer Relations: The Shifting Balance of Power." In Gerry Johnson (Ed.), Business Strategy and Retailing. New York: John Wiley \& Sons. 
Ingene, Charles A. and Mark E. Parry. (1995). "Channel Coordination: The Case of Multiple Retailers With Exclusive Territories," Journal of Retailing, (forthcoming).

Jeuland, Abel and Steven Shugan. (1983). "Managing Channel Profits", Marketing Science, 2(Summer): 239-272.

Kim, Sang Yong and Richard Staelin. (1994). Retail Power: Is it an Illusion? An Analytical Modeling Approach. Working paper, Duke University, Durham, NC.

Kumar, Nirmalya, Louis W. Stern, and Ravi S. Achrol. (1992). "Assessing Reseller Performance from the Perspective of the Supplier," Journal of Marketing Research, 29(2): 238-253.

Lerner, A.P. (1934). "The Concept of Monoploy and the Measurement of Monopoly Power," Review of Economic Studies: 157-175.

Long, William F. and David J. Ravenscraft. (1984). "The Misuse of $\Lambda$ ccounting Rates of Return: Comment," The American Economic Review, (June): 494-500.

Martin, Stephen. (1984). "The Misuse of Accounting Rates of Return: Comment", The American Economic Review, (June): 501-506.

McGuire, Timothy W. and Richard Staelin. (1986). "Channel Efficiency, Incentive Compatibility, Transfer Pricing, and Market Structure: An Equilibrium Analysis of Channel Relationships," Research in Marketing, 8: 181-223.

Megna, Pamela and Dennis Mueller. (1991). "Profit Rates and Intangible Capital," Review of Economics and Statistics: 632-642.

Messinger, Paul and Chakravarti Narasimhan. (1995). "Has Power Shifted in the Grocery Channel?," Marketing Science, 14(2): 189-223.

Ohlson, James A. (1994). "Earnings, Book Values, and Dividends in Security Valuation," Contemporary Accounting Research, forthcoming.

Olver, James M. and Paul W. Farris. (1989). "Push and Pull: A One-Two Punch for Packaged Products," Sloan Management Review, (Fall): 53-61.

Peasnell, K.V. (1981). "On Capital Budgeting and Income Measurement," Abacus, 17(1): 52-67. (1982). "Some Formal Connections Between Economic Values, and Yields and Accounting Numbers," Journal of Business Finance and Accounting, (Autumn): 361-381.

Porter, Michael E. (1974). "Consumer Behavior, Retailer Power and Performance in Consumer Goods Industries," Review of Economics and Statistics, (November): 419-436.

(1976). Interbrand Choice, Strategy, and Bilateral Market Power. Cambridge, MA: Harvard University Press. (1990). The Competitive Advantage of Nations. New York: The Free Press.

Rappaport, Alfred. (1986). Creating Shareholder Value: The New Standard for Business Performance." New York: The Free Press.

Reekie, W. Duncan. (1975). “Advertising and Market Structure: Another Approach," Economic Journal, 85(March): 143-158.

Ross, Stephen A., Randolph Westerfield and Jeffrey Jaffe. (1993). Corporate Finance, 3rd ed. Homewood, IL: Richard D. Irwin Inc.

Sansolo, Michael. (1993). “ECR,” Progressive Grocer, (November): 47-55.

Steiner, Robert L. (1978). "A Dual Stage Approach to the Effects of Brand Advertising on Competition and Price." Pp. 127-150 in John F. Cady (Ed.), Marketing and Public Interest. Report No. 78-105, Marketing Science Institute.

Stern, Louis W. and Adel El-Ansary. (1992). Marketing Channels, 4th ed. Englewood Cliffs, NJ: Prentice Hall.

Stewart, G. Bennett III. (1991). The Quest for Value: A Guide for Senior Managers. New York: Harper Collins.

Stickney, Clyde P. (1995). Financial Statement Analysis: A Strategic Perspective, 3rd ed. (forthcoming). Fort Worth, TX: Dryden Press. 
Sutton, John. (1991). Sunk Costs and Market Structure: Price Competition, Advertising, and the Evolution of Concentration. Cambridge, MA: The MIT Press.

Tully, Shawn. (1993). "The Real Key to Creating Wealth," Fortune Magazine, September 20.

Walbert, Laura. (1993). "America's Best Wealth Creators", Fortune Magazine, December 27.

Wilemon, David L. (1972). "Power and Negotiation Strategies in Marketing Channels," The Southern Journal of Business, 7(February): 12-32.

Wilson, Marianne. (1993). "Home Furnishings Chain Takes the Lead," Chain Store Executive: Corporate Performance, (November): 21-24.

Zimmerman, Richard G. (1959). Advertising Age, August 17. 